\title{
Genotoxic and Mutagenic Effects of Mycotoxins: A Review
}

\author{
Muhsin AYDIN*, Eyyüp RENCÜZOĞULLARI
}

Department of Biology, Faculty of Science and Letters, Adryaman University, 02040, Adryaman, Turkey ORCID ID: Muhsin AYDIN: https://orcid.org/0000-0002-1204-1163; Eyyüp RENCÜZOĞULLARI: https://orcid.org/0000-0001-5206-6421

\begin{abstract}
Received: 15.10 .2019
Accepted: 11.12 .2019

Published online: 20.12 .2019

Issue published: 20.12 .2019

Abstract: In this article, genotoxic and mutagenic effects of mycotoxins that are produced by various fungus species have been reviewed. A total of 259 mycotoxins were found in the literature. Genotoxic effects of 109 of these were investigated. Among the studied mycotoxins, only actinomycin D, aflatoxin, alternariol, chrysazin (dantron), citrinin, fumonisin, mytomycin C, nivalenol, ochratoxin A, patulin, sterigmatocystin, versicolorin A and B, vomitoxin, and zearalenone have sufficient number of studies that present or prove their genotoxic effects. Additional studies are required in order to determine whether other mycotoxins have any genotoxic effects. The current study provides valuable information regarding studied mycotoxins. Therefore, it may lead researchers for designing future mycotoxin-related studies that have never been studied.
\end{abstract}

Keywords: Genotoxicity, mutagenicity, secondary metabolites, possible drugs.

\section{Mikotoksinlerin Genotoksik ve Mutajenik Etkileri: Derleme}

Öz: Bu makalede, çeşitli mantar türleri tarafından üretilen mikotoksinlerin genotoksik ve mutajenik etkileri derlenmiştir. Literatürde toplam 259 mikotoksin bulundu. Bunların 109'unun genotoksik etkileri daha önce araştırıldı. Bugüne kadar yapılmış olan çalışmalarda, çalışılan mikotoksinler arasında sadece aktinomisin D, aflatoksin, alternaril, chrysazin (dantron), sitrinin, fumonisin, mitomisin C, nivalenol, okratoksin A, patulin, sterigmatosistin, versicolorin A ve B, vomitoksin ve zearalenon genotoksik etki göstermiş veya genotoksik etkileri kanıtlanmıştır. Diğer mikotoksinlerin herhangi bir genotoksik etkisi olup olmadığını belirlemek için ek çalışmalar gereklidir. Bu çalışma, daha önce çalışılan mikotoksinler hakkında önemli bilgiler sunmaktadır. Dolayısıyla bu derleme, araştırmacılara, daha önce hiç çalışılmamış olan mikotoksinlerle ilgili gelecekteki çalışmaları tasarlama konusunda katkı sağlayabilir.

Anahtar kelimeler: Genotoksisite, mutajenisite, ikincil metabolitler, muhtemel ilaçlar.

\section{Introduction}

The term "mycotoxin" is derived from the combination of two words: Myco- meaning "fungus" and Toxin meaning "naturally produced poison". Mycotoxins are secondary metabolites produced by fungi such as Aspergillus, Penicillium, Fusarium, Alternaria, Claviceps, and many others. They are natural toxins that have low molecular weight with a wide variety of chemical structures. Mycotoxins produce potent and various toxic effects on humans, animals, and plants (Zain, 2011).

Species belonging to Aspergillus and Penicillium produce the most diverse types of mycotoxins. Among these, the most widely known mycotoxins are Aflatoxins. Aflatoxins cause carcinogenicity, teratogenicity, and mutagenicity in animals. The mode of action of Aflatoxin can be listed as inhibition of DNA, RNA, and protein synthesis, reduction in various enzyme activities, depression of glucose metabolism, inhibition of lipid synthesis including phospholipids, free fatty acids, triglycerides, cholesterol and their esters, and inhibition of the coagulation factors (Hussein \& Brasel, 2001).

In 1970, some tests were developed to quickly determine whether a chemical substance has any mutagenic and/or carcinogenic effects. Since then, a wide variety of investigation systems have been developed for genotoxicity studies. These are mutagenicity tests that detect gene, chromosome or genomic mutations and indicator tests that show other effects that are induced in parallel to the mutation. Most of the recent genotoxicity studies have been done by using cytogenetic methods (CA: Chromosome Aberration, FISH: Fluorescent in situ Hybridization, MN: Micronucleus, and SCE: Sister Chromatid Exchange tests). The cytogenetic methods are capable of determining the structural and numerical chromosome aberrations by using biochemical and electrophoretic methods by detection of DNA damage (adducts, double-strand breaks, cross-linking, alkalinelabile regions, and HGPRT: Hypoxhantine Guanine Phosphoribosyl Transferase gene mutation) (Albertini et al., 2000).

Methods of genotoxicity studies have been continuously evolving. Changes such as large deletions, insertions, inversions, rearrangements, and recombination can be determined at the chromosomal level within the microscopic methods used in routine genotoxicity studies (Noel \& Rath, 2006).

Cytogenetic methods known today as short-term genotoxicity tests and used to determine whether a chemical substance is genotoxic are SCE (Tucker et al., 1993), CA (Carrano \& Natarajan, 1988; Hagmar et al., 1994) and MN (Fenech, 2002; Heddle et al., 1991). These tests can be performed both in vitro in human peripheral lymphocytes and in bone marrow cells of in vivo test animals.

Sister chromatid exchange is an exchange in the DNA replication products between the homologous loci of sister chromatids that repair DNA double chain breaks by homologous recombination (Helleday, 2003; Sonoda et al., 
1999). In humans and animals exposed to substances known to be mutagenic and carcinogenic, it was found out that there is a linear relationship between the increase in the frequency of SCE and the increase in single-gene mutations (Albertini et al., 2000; Carrano \& Natarajan, 1988; Perry \& Evans, 1975). A similar relationship was found between the increase in SCE and the formation of in vivo tumors (Norppa et al., 2006). In contrast to CA, SCE alone is insufficient to determine genotoxic risk. However, in experimental studies, SCE is continued to be used as a suitable indicator method for determining genotoxic effects in humans (Norppa et al., 2006).

Since the development of CA mechanism is similar in different tissues, it is thought that the level of abnormality in lymphocytes is an indicative of the degree of abnormality in cancer-prone tissues and; thus, is indicative of the cancer risk (Albertini et al., 2000; Bonassi et al., 2000; Bonassi, Znaor, Norppa, \& Hagmar, 2004; Bonassi et al., 2005). High CA frequency may be an indicator of high cancer risk, regardless of the reason for initiating CA increase because it has been reported that CA formation may also result from incorrect repairment of chain fractures in DNA (Savage, 1993).

MNs are small nuclei parts that can be found out of the nucleus. The MNs are formed on the telophase due to the acentric chromosome or chromatid fractures that occur when nucleoplasmic bridges (NPB) are formed, stretched, and broken during telophase. Micronuclei formation may also result from chromosome (laggard chromosome) malsegregation during anaphase (Surrallés, Xamena, Creus, \& Marcos, 1995). In addition, multipolar anaphase and telophase cause MN formation (Topaktas \& Rencuzogullari, 2010). The loss of chromosomes that can lead to $\mathrm{MN}$ formation or non-disjunction of the chromosomes are among the major events observed in cancer and aging. This is probably the result of distortion in spindle fibers and centromere or condensation of chromosome structure before metaphase (Dellarco, Mavournin, \& Tice, 1985). Thus, both the clastogenic and aneugenic effects can be determined by the MN test (Kirsch-Volders, Elhajouji, Cundari, \& Van Hummelen, 1997; Norppa \& Falck, 2003). In previous studies, the increase in $\mathrm{MN}$ frequency in peripheral blood lymphocytes from cancer patients was found to be as much as $\mathrm{MN}$ frequency in the cancerous target tissue (Bonassi et al., 2007; Cheng et al., 1996; Duffaud et al., 1997). In addition, Fenech, Holland, Chang, Zeiger, and Bonassi (1999) clearly showed the relationship between $\mathrm{MN}$ and cancer in humans.

Recently, molecular geneticists have developed several new, rapid, and reliable methods for measuring genotoxicity (Swaileh, Hussein, \& Ezzughayyar, 2008; Zhiyi \& Haowen, 2004). One of them is RAPD (Randomly Amplified Polymorphic DNA) technology (Ferrero, Castaño, Gonzalez, Sanz, \& Becerril, 1998; Swaileh et al., 2008). RAPD analysis was developed by Williams, Kubelik, Livak, Rafalski, \& Tingey (1990). This method is simple, sensitive, and very effective in determining genetic damage (Zhiyi \& Haowen, 2004). Also, it gives information about a large number of loci along the genome. The randomly amplified band profiles can be obtained without the need of any information about the target genome or used primers. When electrophoretically observed, changes in band profiles were reported resulted from changes in damage-prone binding sites of genetic material (Becerril,
Ferrero, Sanz, \& Castaño, 1999; Savva, 2000). In addition to changes in the number of bands, changes in band density have also been associated with genetic changes (Atienzar et al., 2000; De Wolf, Blust, \& Backeljau, 2004). This technique is widely used in phylogenetic, taxonomy, ecotoxicology, epidemiological, and genotoxicity studies (Marillia \& Scoles, 1996). Additionally, the bacterial reversion test method using Salmonella typhimurium LT2 strains known as Ames test is also used as mutagenicity test (Maron \& Ames, 1983). Although the above described tests give false positive and false negative results, they are still recommended by some authorities (such as European Food Safety Authority (EFSA) Scientific Committee). In 2011, the EFSA Scientific Committee published an opinion about genotoxicity testing strategies applicable to food and feed safety assessment (EFSA Scientific Committee "Opinion on genotoxicity testing strategies," 2011). As described by the EFSA Scientific Committee, the most commonly used methods for assessing the genotoxic potential of substances are listed as follows together with the relevant Organisation for Economic Co-operation and Development Test Guideline (OECD TG) on the basis of their principal genetic end-point. Bacterial reverse mutation test in Salmonella typhimurium and Escherichia coli (OECD TG 471) and in vitro mammalian cell gene mutation test (OECD TG 476) are used for investigation of point (gene) mutation. In vitro mammalian CA test (OECD 473) and in vitro mammalian cell MN test (OECD TG 487) are used for investigation of CA. On the other hand, the most commonly used in vivo tests can be listed as follows: Mammalian erythrocyte MN test (Test No: 474) and mammalian bone marrow CA test (Test No: 475) are used for investigation of gene mutations, while transgenic rodent somatic and germ cell gene mutation assays (OECD TG 488) are used for CA investigations. Additionally, most common in vivo tests used for primary DNA damage investigations are Comet Assay and Unscheduled DNA synthesis (UDS) test with mammalian liver cells in vivo (OECD TG 486) as described by EFSA Scientific Committee (2011).

Currently, mycotoxins are still one of the most important food contaminant compounds. Along with their carcinogenic effects, mycotoxins can cause to mutations in our genetic structure by showing genotoxic effects. Too many types of mycotoxins have been detected so far. Numerous studies have been done on determining their genotoxic effects. Therefore, the aim of this study is to guide researchers in order to design better experiments by bringing all of the previous results together. In this study, both in vitro and in vivo genotoxic effects of mycotoxins are described in table 1.

\section{Materials and Methods}

A total of 259 mycotoxins were found as a result of the literature review (Atherton \& Betb, 2019; Blanc et al., 1995; Bosio, Siciliano, Gilardi, Gullino, \& Garibaldi, 2017; Chagas, Dias, \& Pupo, 2013; Escrivá, Font, \& Manyes, 2015; Hradil, Hallock, Clardy, Kenfield, \& Strobel, 1989; Kokkonen, Ojala, Parikka, \& Jestoi, 2010; Limón, Rodríguez-Ortiz, \& Avalos, 2010; Lin, Zhang, Wang, Wang, \& Chen, 1998; Mikami et al., 1984; Ostry, 2008). Undoubtedly, this number has been increasing day by day and new mycotoxins are being defined. Genotoxic and mutagenic effects of these mycotoxins have been reviewed by checking previous studies. 
Genotoxicity or mutagenicity tests can be classified as in vitro tests, in vivo tests, bacterial tests (Ames test, also among in vitro tests), and molecular genotoxicity tests. These tests are also referred to as short-term genotoxicity tests. Previously published articles provided information on the advantages and disadvantages, the methodology, and the conditions to be considered of the in vitro testing system (Albertini et al., 2000; Atienzar \& Jha, 2006; KirschVolders et al., 1997; Maron \& Ames, 1983; Norppa \& Falck, 2003; Perry \& Evans, 1975). More detailed information can be obtained from articles published in different years by the OECD (OECD 1986, 1997a, b) and EFSA Scientific Committee (EFSA, 2011, 2017).

More than 341 articles on investigation of genotoxic effects of mycotoxins were found by searching "Mycotoxin names and genotoxicity", "Mycotoxin names and mutagenicity", and "Mycotoxin names and comet assay" key words in PubMed. In these studies, genotoxic effects of various mycotoxins in different organisms were investigated using both in vitro and in vivo cytogenetic methods and molecular genotoxicity methods. In addition, the mutagenicity studies of mycotoxins with the Ames test were also reviewed. The obtained results from examining all previous studies are presented in table-formats (Table 1 and 3$)$.

\section{Results}

A total of 259 mycotoxins were found in the literature. Genotoxic or mutagenic effects of 109 were investigated (Table 1). No studies have been found on the genotoxic or mutagenic effect of the remaining 150 mycotoxins (Table 2). This result shows that we have no knowledge about the genotoxicity or mutagenicity of $57.91 \%$ of all mycotoxins. Additionally, the methods used for cell and tissue types used in genotoxic studies are presented in Table 3.

Table 1. Genotoxic and mutagenic effects of mycotoxins that have been studied.

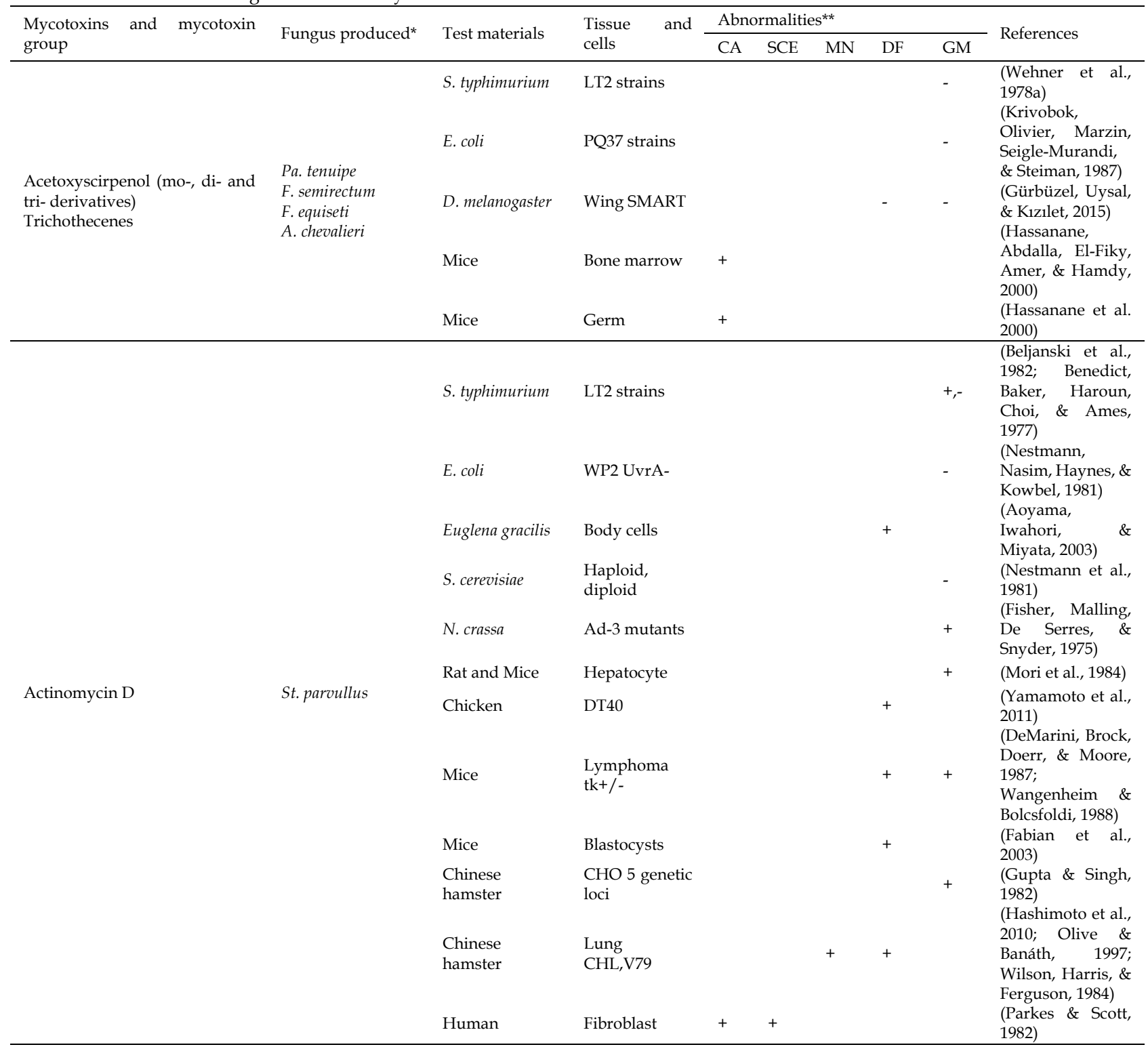




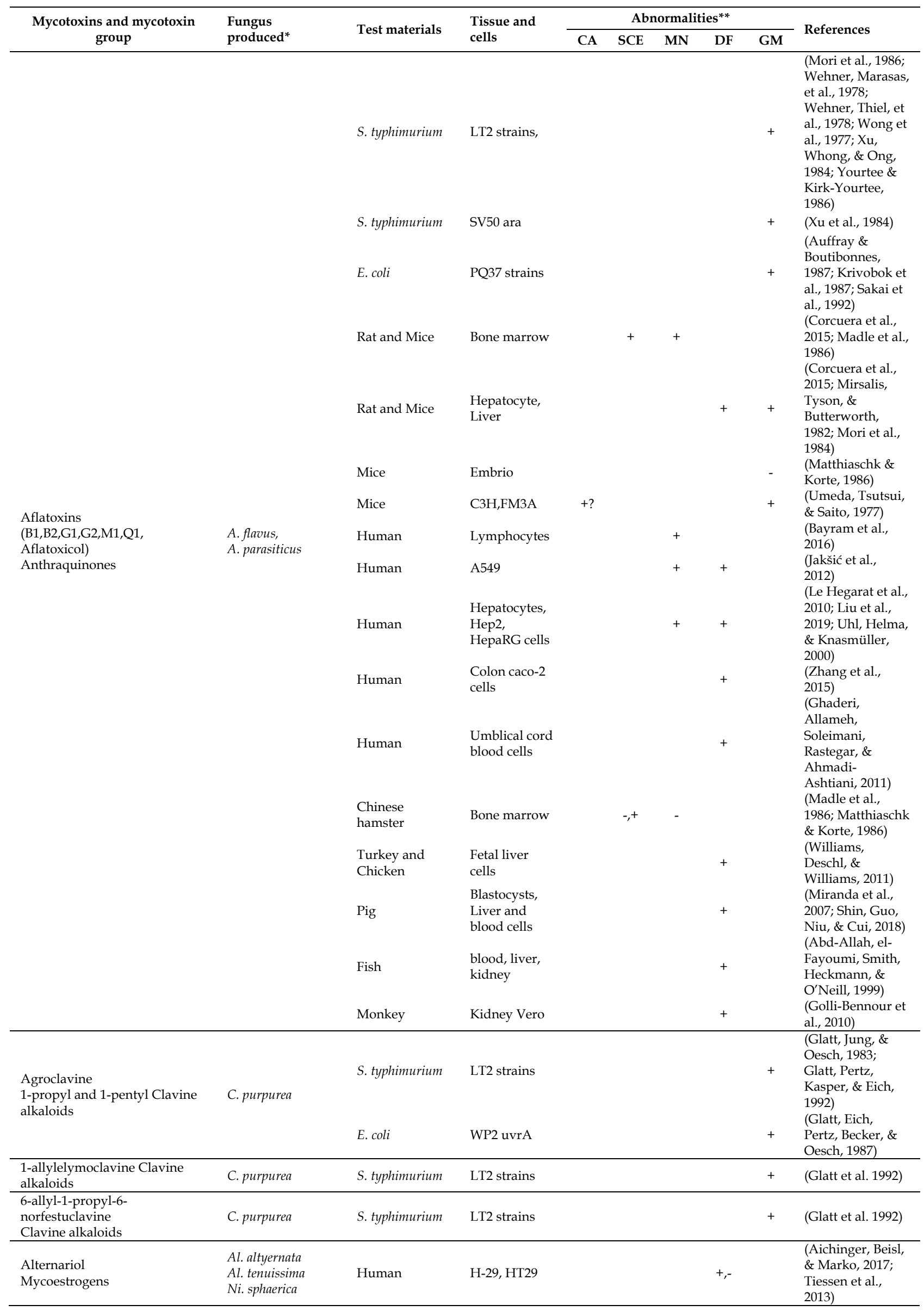




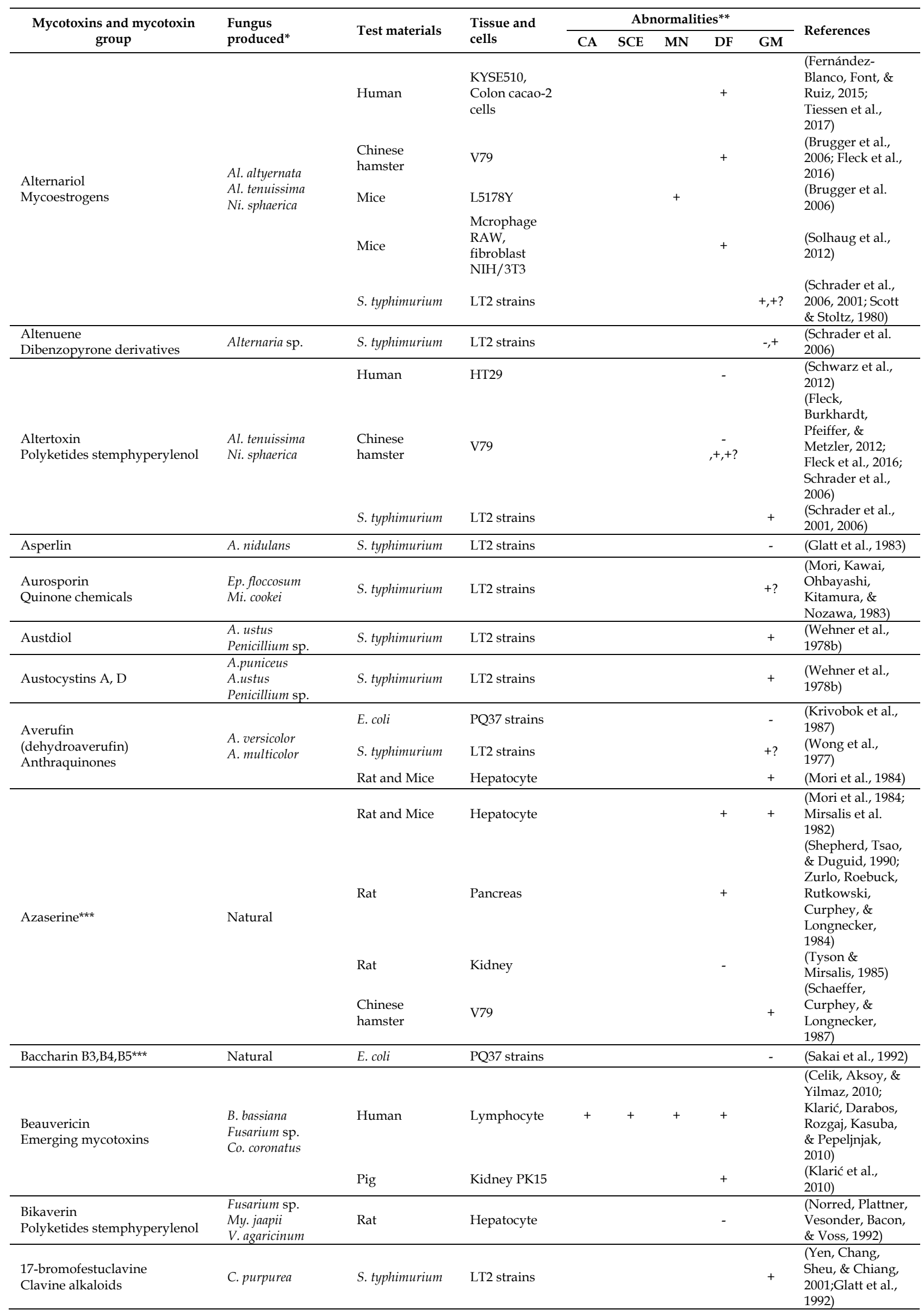




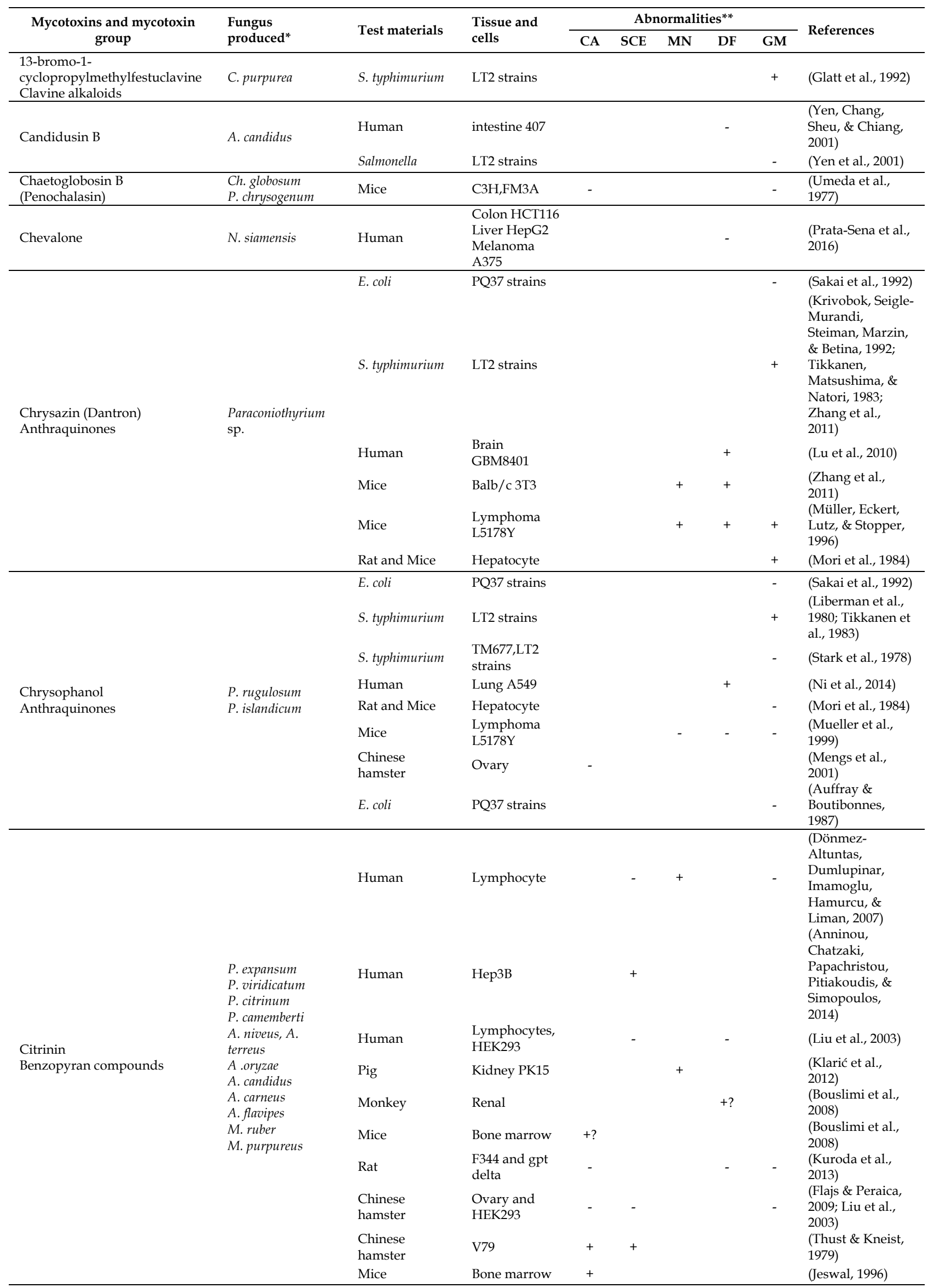




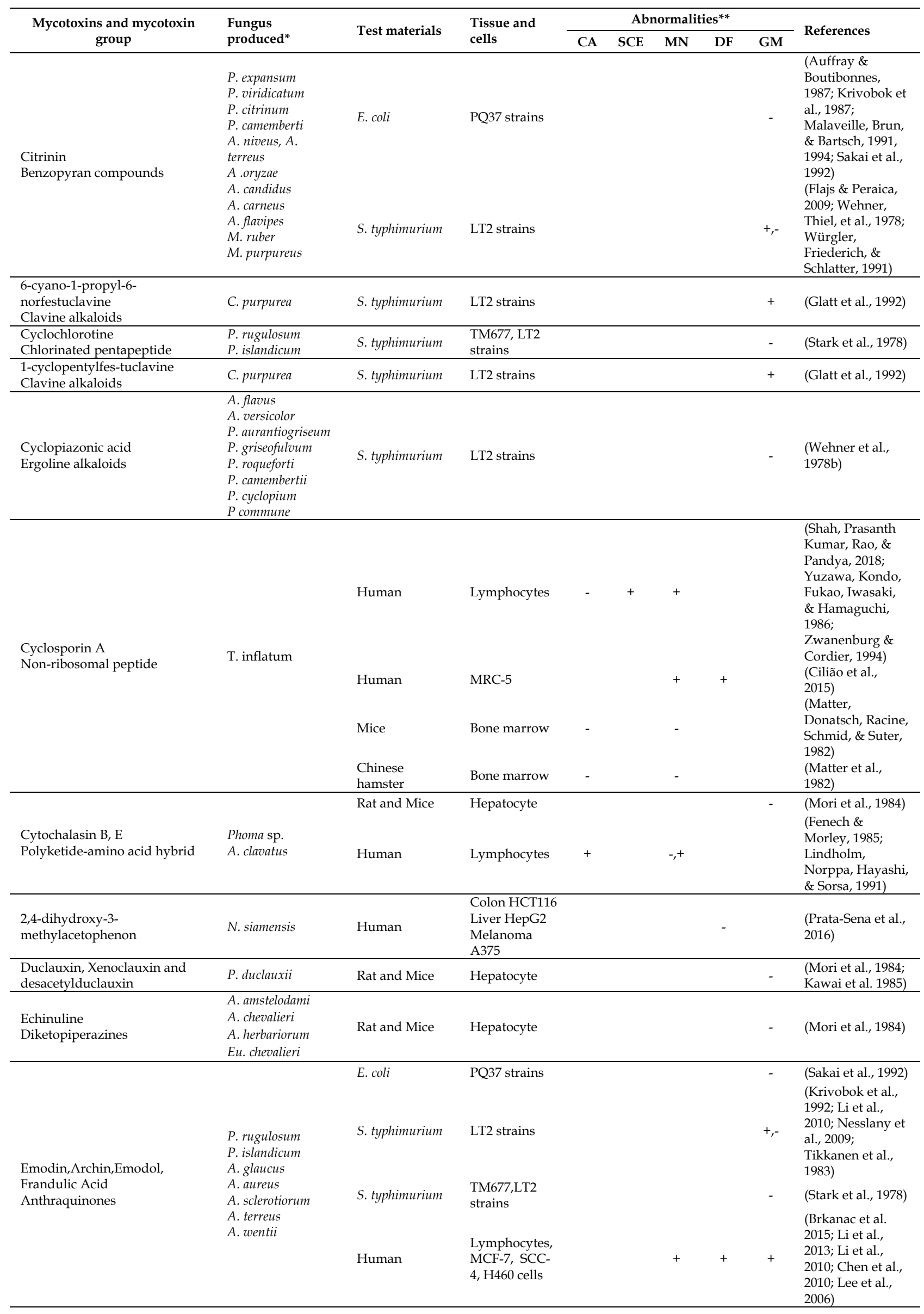




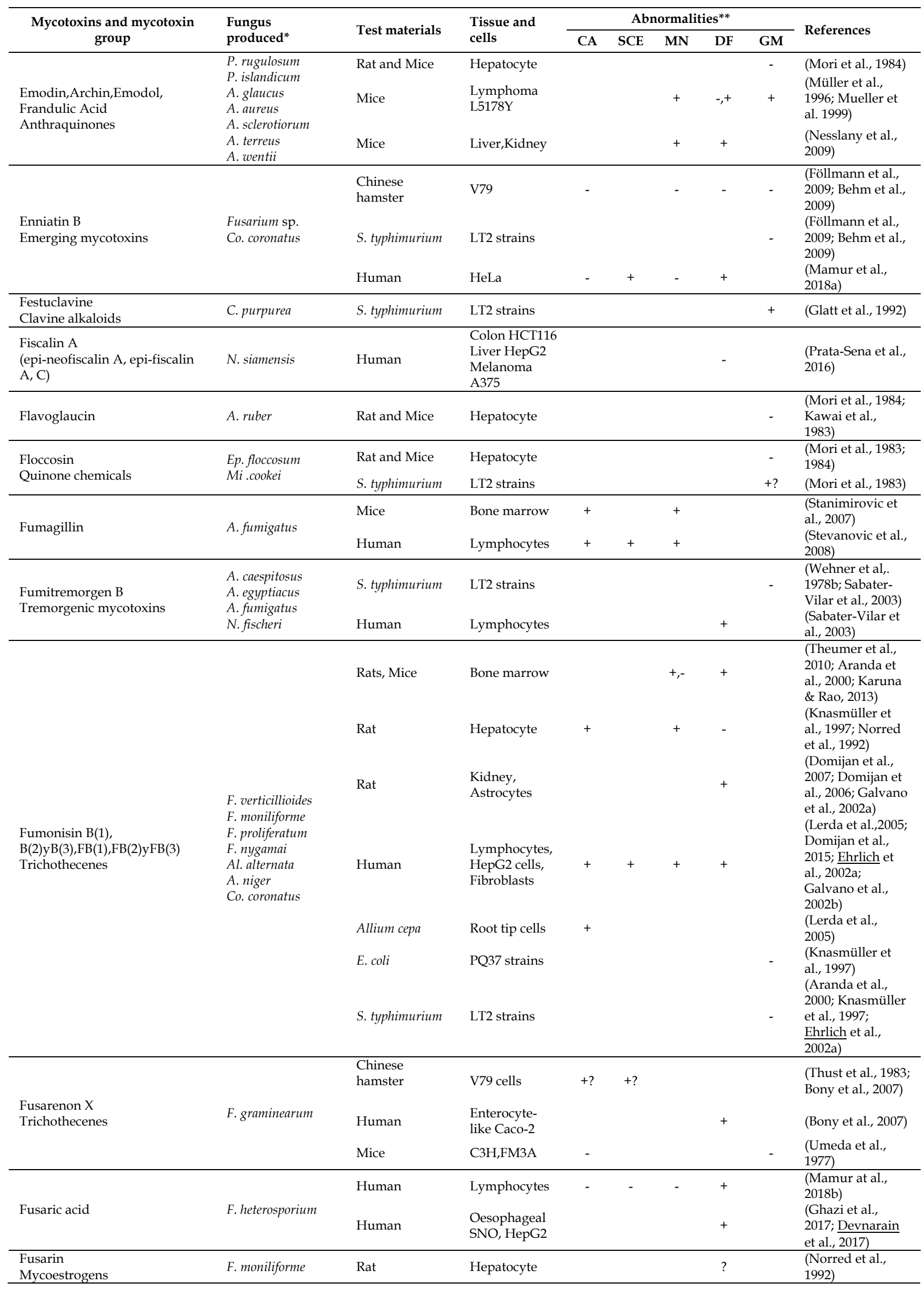




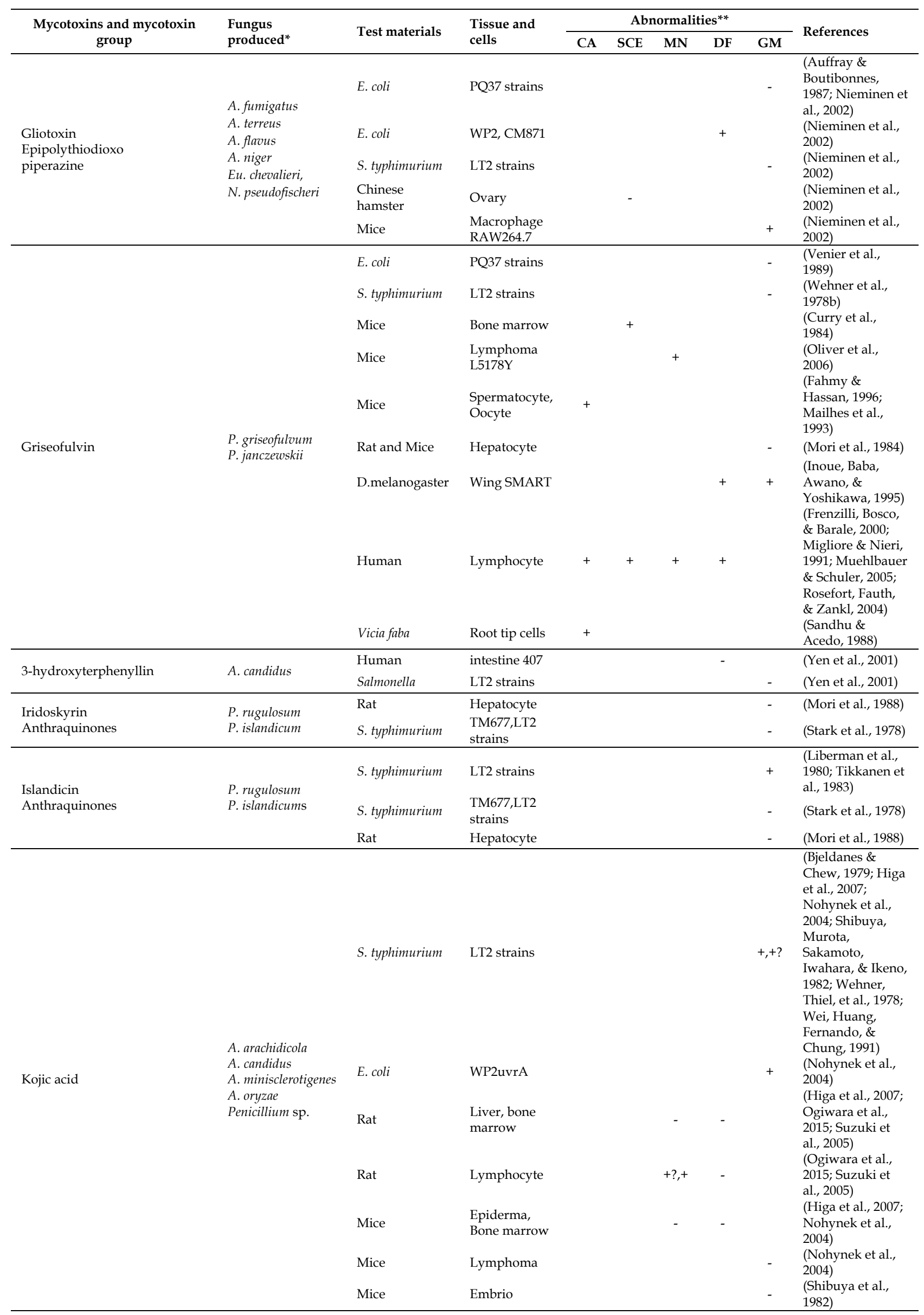




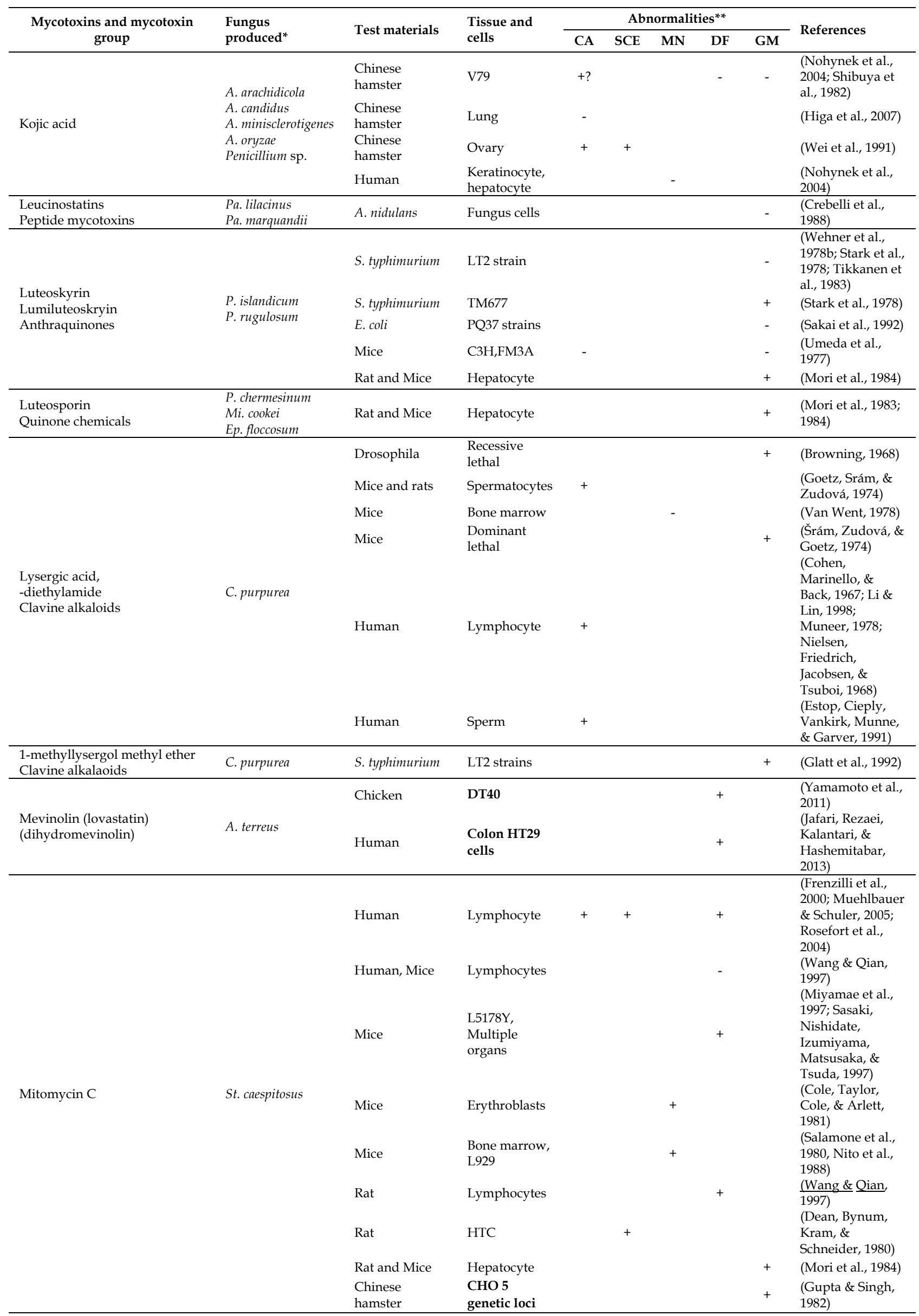




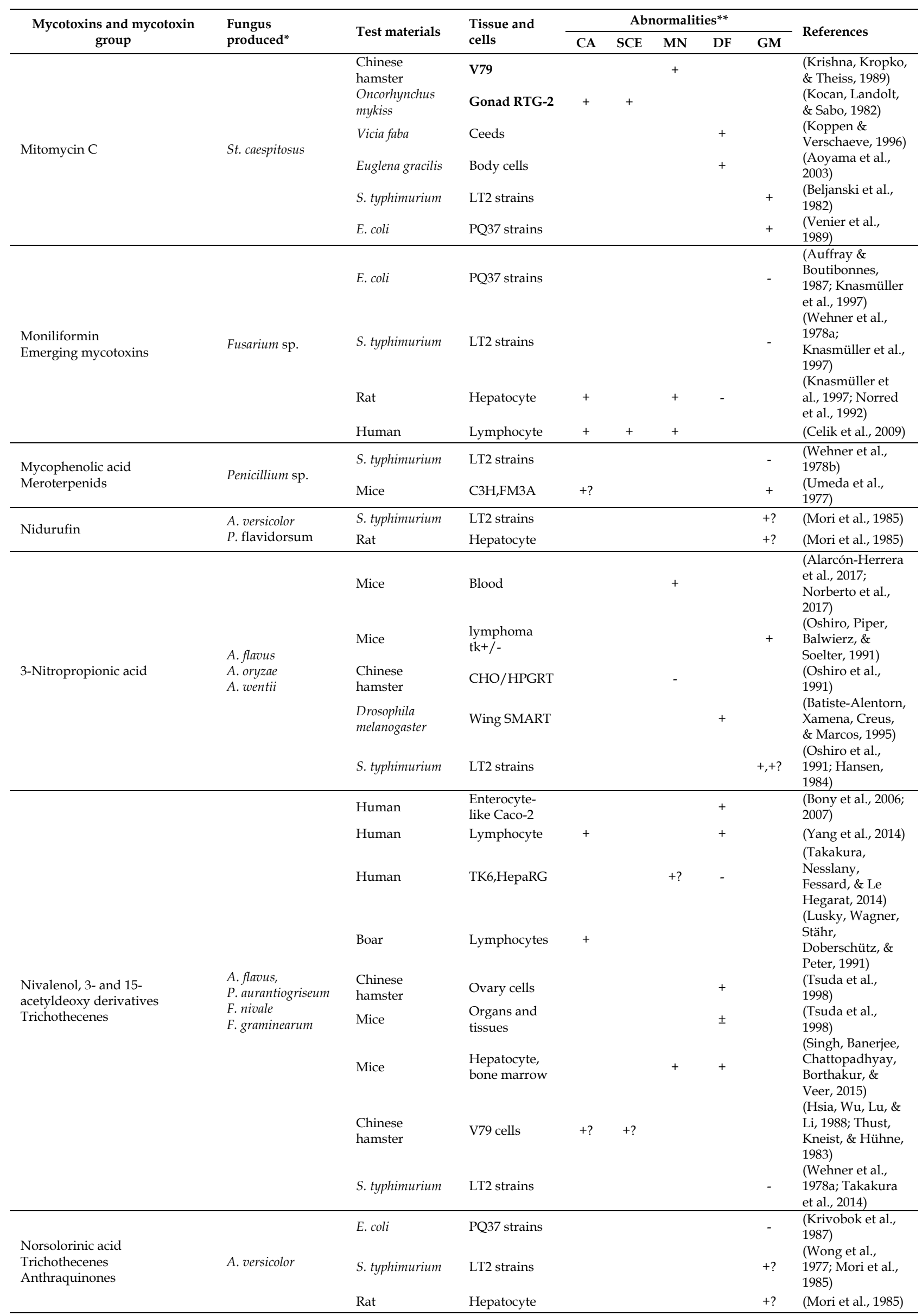




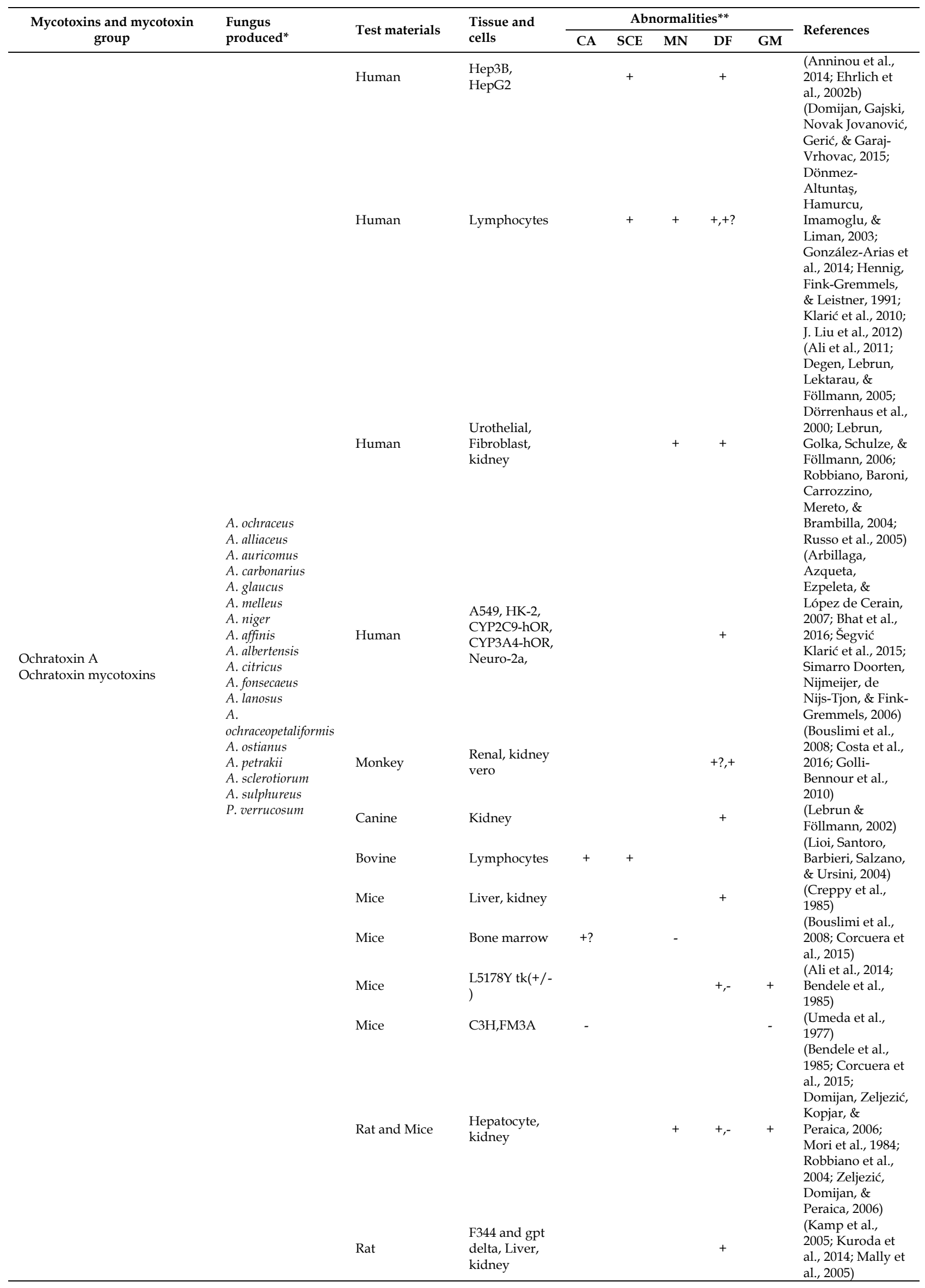




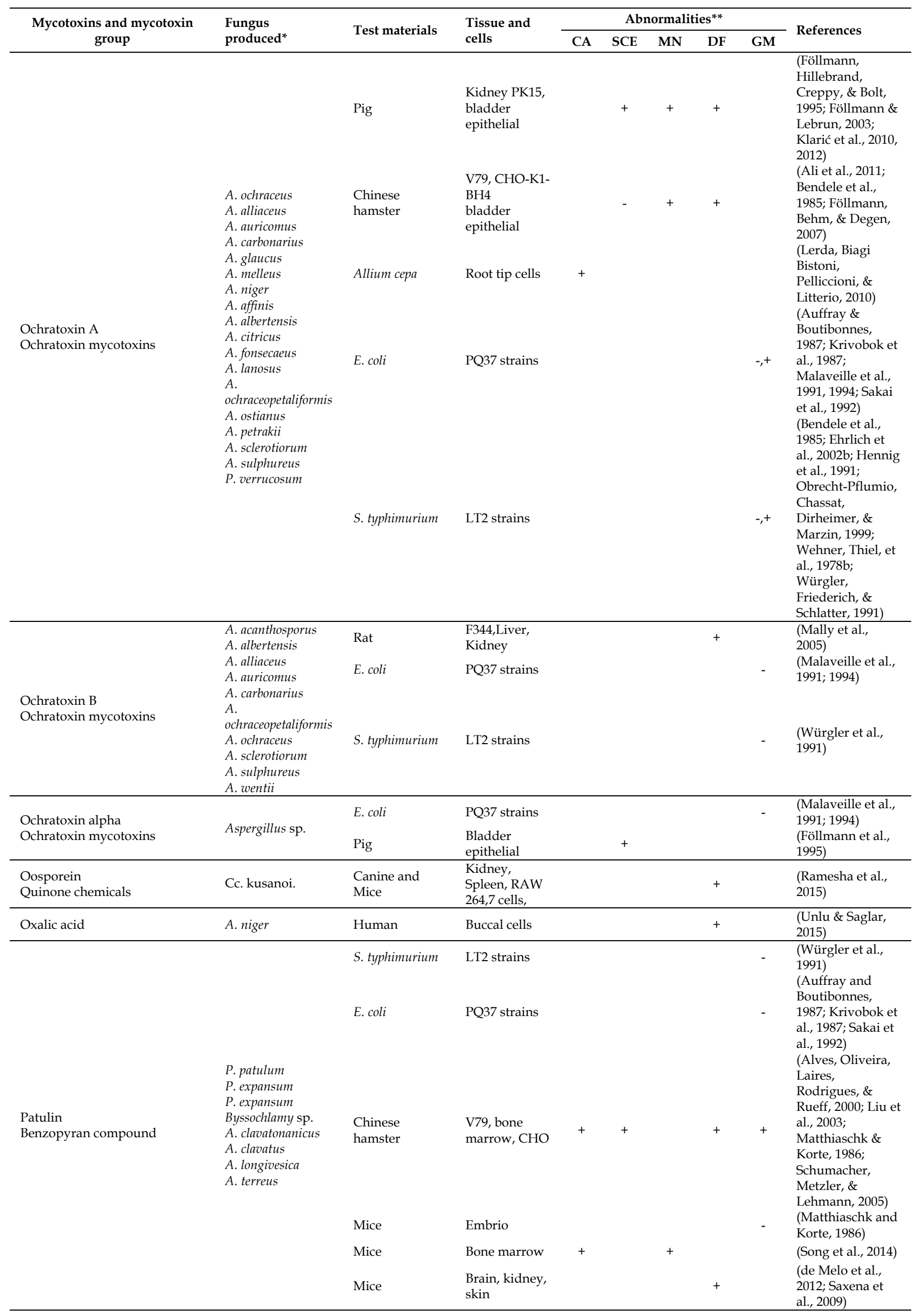




\begin{tabular}{|c|c|c|c|c|c|c|c|c|c|}
\hline \multirow{2}{*}{$\begin{array}{c}\text { Mycotoxins and mycotoxin } \\
\text { group }\end{array}$} & \multirow{2}{*}{$\begin{array}{l}\text { Fungus } \\
\text { produced }\end{array}$} & \multirow{2}{*}{ Test materials } & \multirow{2}{*}{$\begin{array}{l}\text { Tissue and } \\
\text { cells }\end{array}$} & \multicolumn{5}{|c|}{ Abnormalities** } & \multirow{2}{*}{ References } \\
\hline & & & & CA & SCE & MN & DF & GM & \\
\hline \multirow{7}{*}{$\begin{array}{l}\text { Patulin } \\
\text { Benzopyran compound }\end{array}$} & \multirow{7}{*}{$\begin{array}{l}\text { P. patulum } \\
\text { P. expansum } \\
\text { P. expansum } \\
\text { Byssochlamy sp. } \\
\text { A. clavatonanicus } \\
\text { A. clavatus } \\
\text { A. longivesica } \\
\text { A. terreus }\end{array}$} & Mice & C3H,FM3A & + & & & & + & $\begin{array}{l}\text { (Umeda et al., } \\
\text { 1977) }\end{array}$ \\
\hline & & Rat and Mice & Hepatocyte & & & & & - & (Mori et al., 1984) \\
\hline & & Human & $\begin{array}{l}\text { Lymphocytes, } \\
\text { HEK293 }\end{array}$ & & + & & + & & (Liu et al., 2003) \\
\hline & & & & & & & & & (Alves et al., 2000; \\
\hline & & & & & & & & & Donmez- \\
\hline & & Human & Lymphocytes & & & + & & & $\begin{array}{l}\text { Altuntas, Gokalp- } \\
\text { Yildiz, Bitgen, \& } \\
\text { Hamurcu, 2013) } \\
\text { (Zhou, Jiang, }\end{array}$ \\
\hline & & Human & HepG2 & & & + & + & & $\begin{array}{l}\text { Geng, Cao, \& } \\
\text { Zhong, 2009, } \\
\text { 2010) }\end{array}$ \\
\hline \multirow{2}{*}{$\begin{array}{l}\text { Paxilline } \\
\text { Tremorgenic mycotoxins }\end{array}$} & \multirow{2}{*}{$\begin{array}{l}\text { Aspergillus sp. } \\
\text { Penicillium sp. } \\
\text { Claviceps sp }\end{array}$} & S. typhimurium & LT2 strains & & & & & - & $\begin{array}{l}\text { (Sabater-Vilar, } \\
\text { Nijmeijer, \& Fink- } \\
\text { Gremmels, 2003) }\end{array}$ \\
\hline & & Human & Lymphocytes & & & & + & & $\begin{array}{l}\text { (Sabater-Vilar et } \\
\text { al., 2003) }\end{array}$ \\
\hline \multirow[t]{3}{*}{$\begin{array}{l}\text { Penicillic acid } \\
\text { Isopropylidene tetronic acid }\end{array}$} & \multirow[t]{3}{*}{$\begin{array}{l}\text { P. roqueforti } \\
\text { P. camemberti } \\
\text { Aspergillus sp. }\end{array}$} & S. typhimurium & PQ37 strains & & & & & - & $\begin{array}{l}\text { (Wehner et al., } \\
\text { 1978b) } \\
\text { (Krivobok et al., } \\
\text { 1987; Auffray \& } \\
\text { Boutibonnes, } \\
\text { 1987) }\end{array}$ \\
\hline & & Mice & $\mathrm{C} 3 \mathrm{H}, \mathrm{FM} 3 \mathrm{~A}$ & + & & & & + & $\begin{array}{l}\text { (Umeda et al., } \\
\text { 1977) }\end{array}$ \\
\hline & & Rat and Mice & Hepatocyte & & & & & - & (Mori et al., 1984) \\
\hline \multirow{2}{*}{$\begin{array}{l}\text { Penitrem A } \\
\text { Tremorgenic mycotoxins }\end{array}$} & \multirow{2}{*}{ P. crustosum } & Human & Lymphocytes & & & & - & & $\begin{array}{l}\text { (Sabater-Vilar et } \\
\text { al., 2003) }\end{array}$ \\
\hline & & S. typhimurium & LT2 strains & & & & & - & $\begin{array}{l}\text { (Sabater-Vilar et } \\
\text { al., 2003) }\end{array}$ \\
\hline \multirow{2}{*}{$\begin{array}{l}\text { Physcion } \\
\text { Anthraquinones }\end{array}$} & \multirow{2}{*}{$\begin{array}{l}\text { Microsporum sp. } \\
\text { A. glaucus }\end{array}$} & S. typhimurium & LT2 strains & & & & & + & $\begin{array}{l}\text { (Krivobok et al., } \\
\text { 1992) }\end{array}$ \\
\hline & & Mice & $\begin{array}{l}\text { Lymphoma } \\
\text { L5178Y }\end{array}$ & & & - & - & - & $\begin{array}{l}\text { (Mueller et al., } \\
\text { 1999) }\end{array}$ \\
\hline Pibasterol & $\begin{array}{l}\text { P. rugulosum } \\
\text { P. islandicum }\end{array}$ & S. typhimurium. & $\begin{array}{l}\text { TM677,LT2 } \\
\text { strains }\end{array}$ & & & & & - & (Stark et al., 1978) \\
\hline \multirow[t]{3}{*}{ PR toxins } & \multirow[t]{3}{*}{$\begin{array}{l}\text { P. roqueforti } \\
\text { P. camemberti }\end{array}$} & S. typhimurium & PQ37 strains & & & & & - & $\begin{array}{l}\text { (Auffray \& } \\
\text { Boutibonnes, } \\
\text { 1987; Sakai et al., } \\
\text { 1992) } \\
\text { (Moulé, } \\
\text { Hermann, \& } \\
\text { Renault, 1981; Xu } \\
\text { et al., 1984) }\end{array}$ \\
\hline & & S. typhimurium & SV50 ara & & & & & + & (Xu et al., 1984) \\
\hline & & $\begin{array}{l}\text { Chinese } \\
\text { hamster }\end{array}$ & V79 & & - & & & & $\begin{array}{l}\text { (Moulé et al., } \\
\text { 1981) }\end{array}$ \\
\hline Radicinin & Al. alternata & S. typhimurium & LT2 strains & & & & &,-+ & $\begin{array}{l}\text { (Schrader et al., } \\
2001 ; 2006) \\
\end{array}$ \\
\hline $\begin{array}{l}\text { Roquefortine } \\
\text { Diketopiperazines }\end{array}$ & $\begin{array}{l}\text { P. roqueforti } \\
\text { P. camemberti } \\
\end{array}$ & S. typhimurium & LT2 strains & & & & & - & $\begin{array}{l}\text { (Schoch, Lüthy, \& } \\
\text { Schlatter, 1984) }\end{array}$ \\
\hline $\begin{array}{l}\text { Roridin A } \\
\text { Trichothecenes }\end{array}$ & $\begin{array}{l}\text { Mr. roridum } \\
\text { Cylindocarpon sp. }\end{array}$ & E. coli & PQ37 strains & & & & & - & (Sakai et al., 1992) \\
\hline $\begin{array}{l}\text { Rubratoxin B } \\
\text { Alpha, beta unsatu-rated } \\
\text { lactone }\end{array}$ & P. rubrum & E. coli & PQ37 strains & & & & & - & (Sakai et al., 1992) \\
\hline \multirow{3}{*}{$\begin{array}{l}\text { Rubroskyrin } \\
\text { Anthraquinones }\end{array}$} & \multirow{3}{*}{$\begin{array}{l}\text { P. rugulosum } \\
\text { P. islandicum }\end{array}$} & S. typhimurium & TM677s & & & & & + & (Stark et al., 1978) \\
\hline & & S. typhimurium & LT2 strains & & & & & - & (Stark et al., 1978) \\
\hline & & Rat & Hepatocyte & & & & & - & (Mori et al., 1988) \\
\hline \multirow{4}{*}{$\begin{array}{l}\text { Rugulosin } \\
\text { Anthraquinones }\end{array}$} & \multirow{4}{*}{$\begin{array}{l}\text { P. rugulosum } \\
\text { P. islandicum }\end{array}$} & E. coli & PQ37 strains & & & & & - & (Sakai et al., 1992) \\
\hline & & S. typhimurium & LT2 strains & & & & &,$-+?$ & $\begin{array}{l}\text { (Tikkanen et al., } \\
\text { 1983; Stark et al., } \\
\text { 1978; Krivobok et } \\
\text { al., 1992; Mori et } \\
\text { a., 1983) }\end{array}$ \\
\hline & & S. typhimurium & TM677 & & & & & + & (Stark et al., 1978) \\
\hline & & Rat and Mice & Hepatocyte & & & & & - & $\begin{array}{l}\text { (Mori et al., 1983; } \\
\text { 1984) }\end{array}$ \\
\hline $\begin{array}{l}\text { Satratoxin } \mathrm{H} \\
\text { Trichothecenes }\end{array}$ & $\begin{array}{l}\text { S. chartarum } \\
\text { S. atra }\end{array}$ & Rat & P12 & + & & + & - & + & $\begin{array}{l}\text { (Nusuetrong et } \\
\text { al., 2012) }\end{array}$ \\
\hline
\end{tabular}




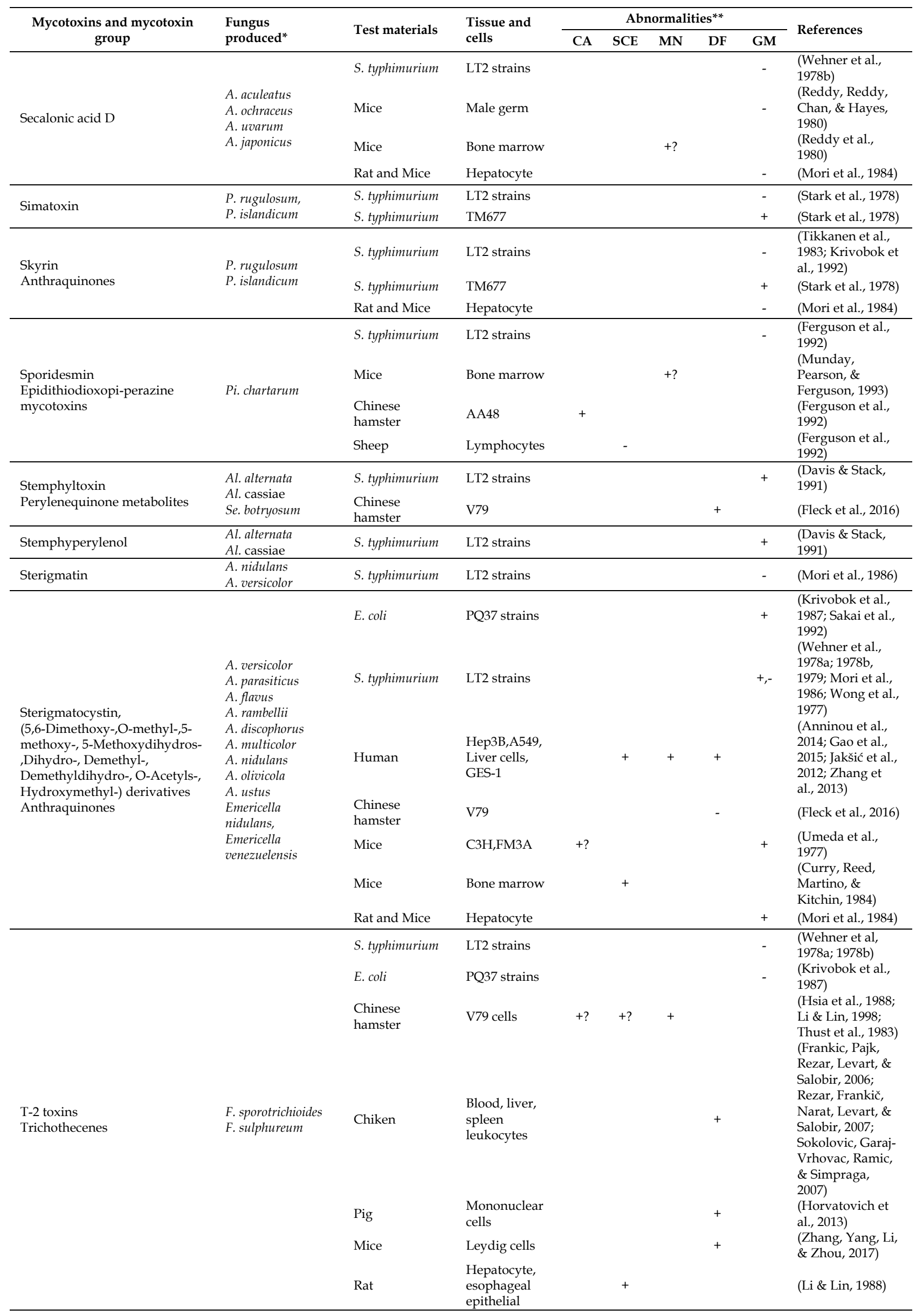




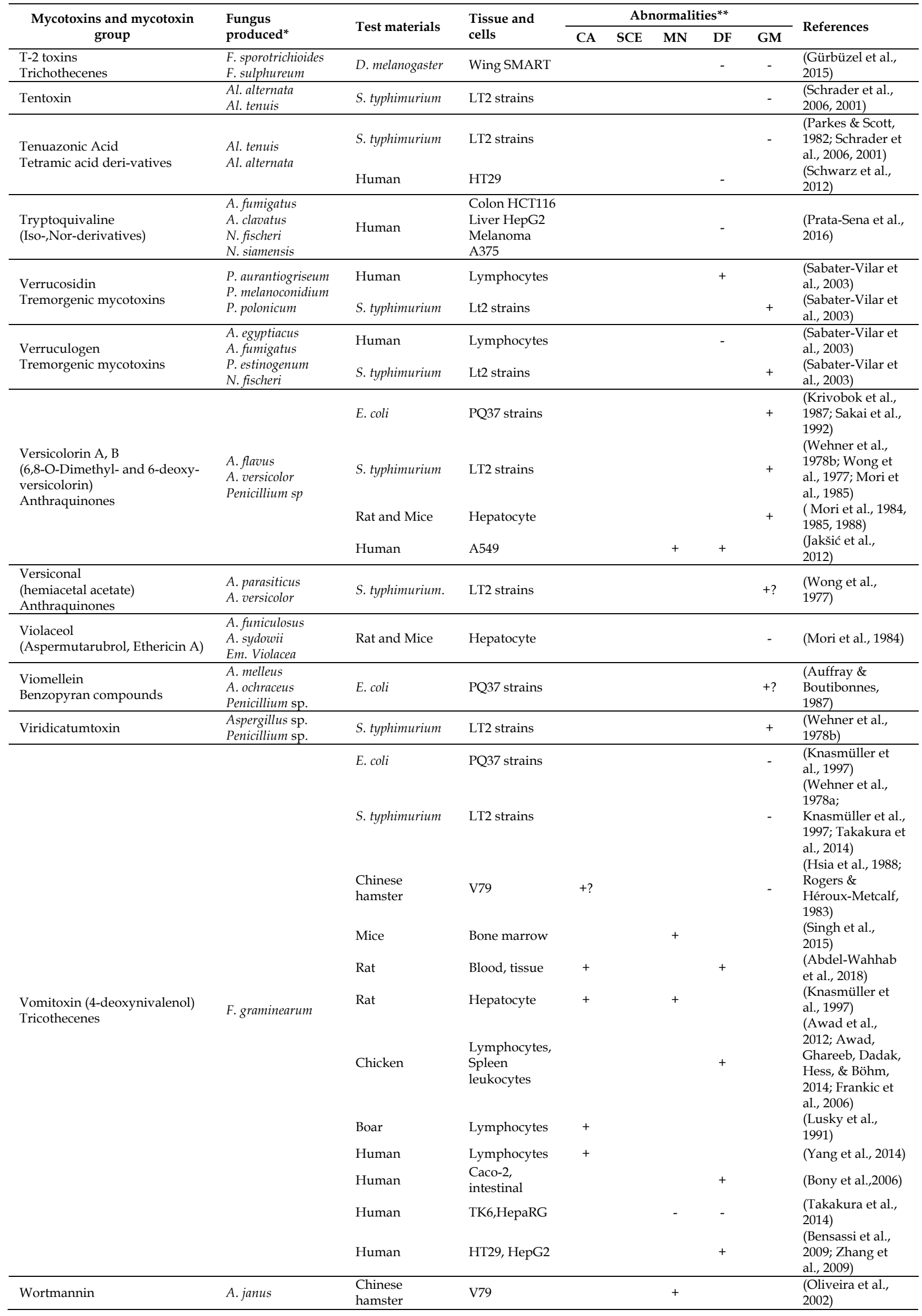




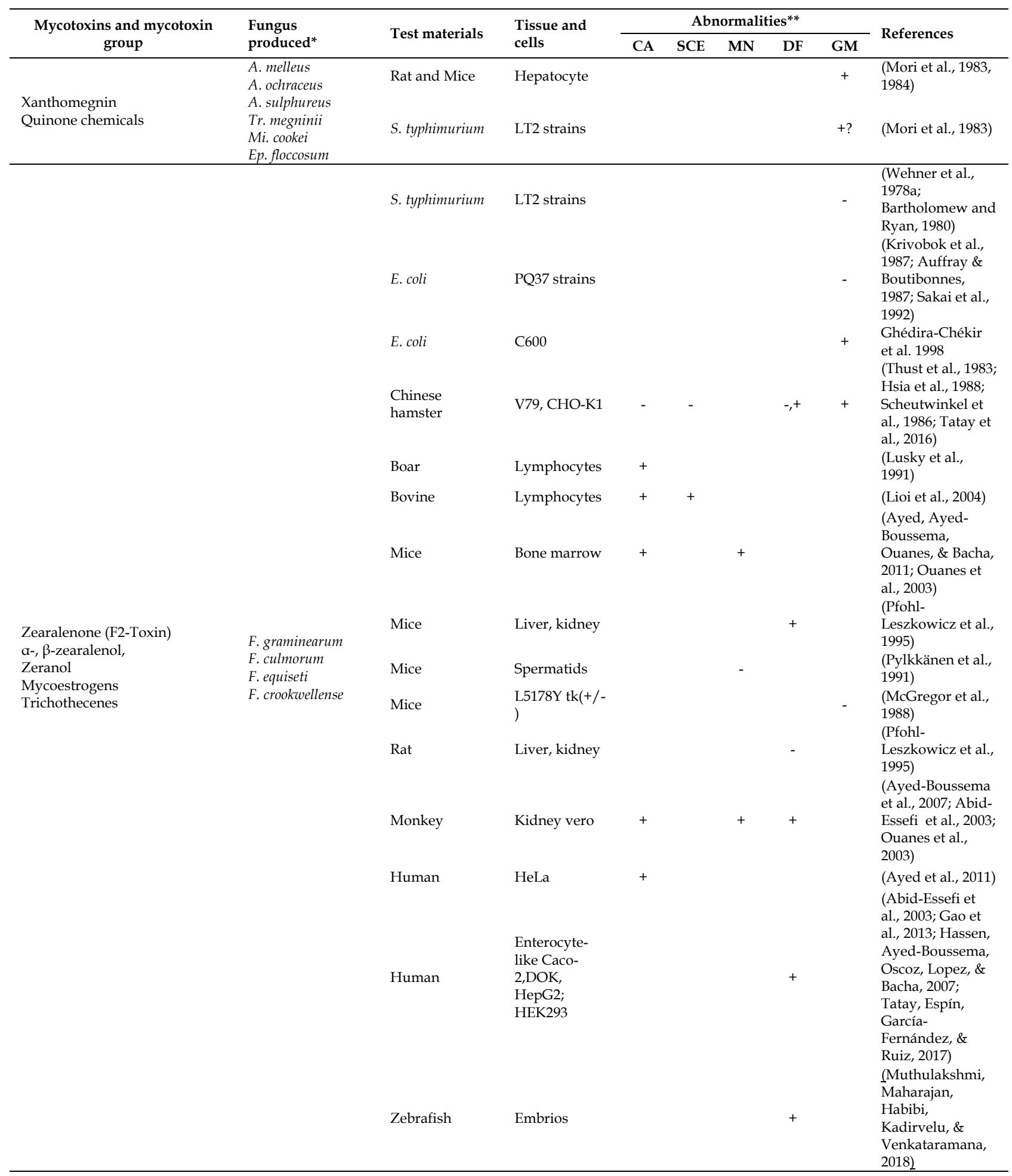

*A:Aspergillus sp.; Al:Alternaria sp.; B:Beauveria sp.; C:Claviceps sp.; Ch:Chaetomium sp.; Co:Conidiobolus sp; Cc: Cochliobolus sp.; E:Eupenicillium sp.; Em:Emericella sp.; Ep:Epidermophyton sp.; Eu:Eurotium sp.; F:Fusarium sp.; M:Monascus sp.; Mr:Myrothecium sp.; Mi:Microsporum sp.; My:Mycogone sp.; N:Neosartorya sp.; Ni:Nigrospora sp.; P:Penicillium sp; Pa:Paecilomyces sp; Pi:Pithomyces sp.; Po:Podostroma sp.; S:Stachybotrys sp; Se:Stemphylium sp.; St:Streptomyces sp; T:Tolypocladium sp.; Tr:Trichophyton sp.; V:Verticillium sp.

${ }^{* *}$ CA:Structural and numerical chromosome abnormalities; SCE:Sister chromatid exchanges; MN:Micronucleus; DF:DNA fragmentations, Unsheduled DNA synthesis, Comet assay; GM:Gene mutation, Nucleotide substitution, Dominant lethal mutation. $(+)$ :genotoxic or mutagenic; (-):non-genotoxic or non-mutagenic; (+?):weakly or moderately genotoxic or mutagenic; (?):inconclusive (questionable) results; $( \pm)$ : in some tissues of animals are genotoxic or mutagenic and in other tissues are non-genotoxic or non-mutagenic

*** Baccharin, a component of Brazilian propolis, isolated from natural plant Baccharis dracunculifolia DC (Asteraceae). It was evaluated as a mycotoxin. ${ }^{92,143}$ Azaserine (9-diazoacetyl-L-serine) is a natural diazoazetyl amino acids (dipeptide). It was evaluated as a mycotoxin (Mori et al. 1984). 
Table 2. List of mycotoxins that have not been investigated in terms of genotoxic and mutagenic effects

\begin{tabular}{|c|c|c|c|}
\hline 13-O-Methylviriditin & Dihydrogeodin & Astellolide B & Kotanin \\
\hline $\begin{array}{l}\text { 2-hydroxy-3-methyl-1,4- } \\
\text { benzoquinone }\end{array}$ & Dihydroxyaflavinine & Astepyrone metabolite $3,4,6$ & Lolitrem \\
\hline $\begin{array}{l}\text { 2-Methyl-1,4-benzoquinone 5,6- } \\
\text { epoxide }\end{array}$ & Dioxopiperazine & Asterric acid & Malformins \\
\hline 2"-oxoasterriquinol D Me ether 1 & Dithiosilvatin & Asterriquinone (Demethyl) B1, B3, D, A4,C2 & Maltoryzine \\
\hline 3'-hydroxy HT-2 toxin & Ditryptophenoline & Auranthine & Mellein (Ochracin) \\
\hline 3'-Hydroxy T-2 triol & Emestrin & Auroglaucine & Methoxyhydroxyheptadienylbenzyl \\
\hline 3-Furanacetic acid & Emethacin & Austamide & Mevalonate \\
\hline 3-Methylorsellinic acid & Equisetin & Austin (Deacetylaustin) & Monascidin A \\
\hline Aflatrem & Erdin & Azaphilon & Naphthalic anhydride \\
\hline Aflavinine & Erythroglaucin & Benzylbismethylthiopiperazinedione & Naphthazarin epoxide \\
\hline Alanyltryptophan anhydride & Ethanedioc acid & Bianthrone & N-benzoyl-L-phenylalaninol \\
\hline Alpha-sarcin & Flavipin & b-Resorcylaldehyde-a-14C & Neoechinuline \\
\hline Alteichin & Flavoglaucin & b-Resorcylic-carboxy-14C & Neosartorin \\
\hline Alterperylenol & Frequentin & Brevianamide & Neosolaniol \\
\hline Andibenin C & Fumigaclavine & Butanedioic acid & Nidulin \\
\hline Andilesin & Fumitoxin & Butenolide & Nidulol \\
\hline Anditomin & Fusaproliferin & Butyrolactone & Norisotryptoquivaline \\
\hline $\begin{array}{l}\text { Aranotin } \\
\text { bisdethiobismethylthioacetyl }\end{array}$ & Fusarochromanone & Canescin & O-ethylparvulenone \\
\hline Asparvenone & Geodin 1 (Dihydrogeodin) & Carboxydiphenylbutenoic anhydride & Rubrocristin \\
\hline Asperfuran & O-Methylasparvenone & Catenarin & Scleramide \\
\hline Asperfuranone & O-methylparvulenone & Chlorflavonin & Sclerin \\
\hline Aspergillic acid & Orlandin & Chloromethyresorcyloylhydroxyanisinate & Siderine \\
\hline Aspermutarubrol & Pachybasin & Chrysogine & Silvaticamide \\
\hline Asperphenamate & Palitantin & Cichorine & Silvaticol \\
\hline Asperthecin & Paraherquamide & cis-4-Hydroxymellein & Sphingofungin \\
\hline Aspertoxin & Paspalicine & Citraconic anhydride & Spinulosin \\
\hline Aspochalasin A,B,D & Paspaline (Paspalinine) & Cladosporin & Sulochrin \\
\hline Aspulvinone & Paspalitrem & Gregatin & Sydonic acid \\
\hline Compactin & Pergillin & Helvolic acid & Sydonol \\
\hline Crotocin & Phenprocoumon & Hexanoic & Terphenyllin \\
\hline Cryptoechinuline & Phomopsin & HT-2 toxin & Terreic acid \\
\hline Cyclopaldic acid & Phthalide (Chromanol) & Hydrazinecarboxamide & Terrein \\
\hline D-Altritol Species & Physcionanthrone & Hydroxysydonic acid & Terremutin \\
\hline Deacetylaustin & Preechinulin & Indole Species & Terretonin \\
\hline Dechloronidulin & Questin & Isodihydroauroglaucin & Territrem \\
\hline Desmethylkotanin & Regulin & Isoflumigaclavines & Parasiticol \\
\hline Destruxin & $\begin{array}{l}\text { Roridin A, } \\
\text { (Diepoxyroridin) }\end{array}$ & Itaconic acid & \\
\hline Dihydroalterperylenol & Aspyrone & Janthitrems & \\
\hline
\end{tabular}

Table 3. Test protocol for cell and tissue types used in genotoxic studies

\begin{tabular}{llll}
\hline Test Materials & Tissue and cells & Test Protocols & References \\
\hline S. typhimurium & LT2 strains & Ames Test & (Maron \& Ames, 1983) \\
S. typhimurium & SV50 ara & Forward Mutation Assay & $($ Xu et al., 1984) \\
E. coli & PQ37 strains & SOS Chromotest & (Quillardet et al., 1982) \\
E. coli & WP1 and WP2 UvrA & UvrA reverse Mutation Assay & (Nestmann et al., 1981) \\
S. cerevisiae & Haploid, diploid strains & Gene Conversion and Mitotic & (Nestmann et al., 1981) \\
D.melanogaster & Wing & Recombination Tests & (Graf et al., 1984)
\end{tabular}




\begin{tabular}{|c|c|c|c|}
\hline Test Materials & Tissue and cells & Test Protocols & References \\
\hline Rodents and other animals & Bone marrow cells & In vivo $\mathrm{CA}, \mathrm{SCE}$ and $\mathrm{MN}$ Methods & $\begin{array}{l}\text { (DeMarini et al., 1987; Wangenheim \& } \\
\text { Bolcsfoldi, 1988) (OECD, 1996; } \\
\text { Rencuzogullari \& Aydin, 2018) }\end{array}$ \\
\hline Rodents and other animals & Erythrocytes & $\begin{array}{l}\text { Mammalian Erythrocyte } \\
\text { Micronucleus Tests }\end{array}$ & (OECD, 2013; Rencuzogullari \& Aydin, 2018) \\
\hline Rodents and other animals & DT40 or other tissue cells & CometAssay & (Yamamoto et al., 2011) \\
\hline Rodents and other animals & $\begin{array}{l}\text { Hepatocytes and orther } \\
\text { tissues cells }\end{array}$ & DNA Repair Test & (Mori et al., 1984) \\
\hline Rodents and other animals & Germ cells & Germ Cells Mutation Test & (Hassanane et al., 2000; Marchetti et al., 2018) \\
\hline Rodents and other animals & Lymphoma TK 4/- & Forward Mutation Assay & $\begin{array}{l}\text { (Wangenheim and Bolcsfoldi, 1988; DeMarini } \\
\text { et al., 1987) }\end{array}$ \\
\hline Human and Rodents & $\begin{array}{l}\text { Peripheral blood cells or } \\
\text { other tissues cells }\end{array}$ & $\begin{array}{l}\text { In vitro } \mathrm{CA}, \mathrm{SCE} \text { and } \mathrm{MN} \\
\text { Methods }\end{array}$ & $\begin{array}{l}\text { (Evans, 1984; Perry and Thompson, 1984; } \\
\text { Kirsch-Volders et al., 1997; Albertini et al., } \\
\text { 2000; Rencuzogullari \& Aydin, 2018) }\end{array}$ \\
\hline Human & Cancer cells & MTT Test or Comet Assay & (Prata-Sena et al., 2016) \\
\hline
\end{tabular}

When Table 1 is examined, it can be seen that the genotoxic or mutagenic effect of many mycotoxins is investigated with only one test (46 mycotoxin) or two tests (24 mycotoxin) system. These mycotoxins may also be considered among mycotoxins that have not been determined genotoxic or mutagenic toxins because the genotoxic effect of any mycotoxin or a chemical is only tested with a test battery in order to say that the results are reliable. The test group, called the test battery, should contain an in vitro or in vivo test and should consist of a bacterial test system such as the Ames test. The results will be more reliable when molecular tests such as RAPD-PCR included in the system. Therefore, the number of mycotoxins that we do not know about their genotoxic effects increases when we take these mycotoxins among the unexplained ones.

Cytochalasin and fumagillin are the two mycotoxins effects of which were studied in vivo in rodents and in vitro human lymphocytes without any bacterial test system. Cytochalasin has genotoxic effect only in human lymphocytes, while fumagillin has genotoxic and mutagenic effects in all tests (Banerjee \& Paruthy, 2016). In particular, in vivo tests are extremely important in terms of presenting mycotoxin metabolism. Floccosin, iridoskyrin, islandicin, mycophenolic acid, nidurufin, norsolorinic acid, rubroskyrine, and skyrin are the mycotoxins genotoxic effects of which were investigated by both in vivo and bacterial test (Aleksic et al., 2017). It can be said that there is a non-genotoxic or suspected genotoxic effect in all of the mentioned mycotoxins.

It is important to study candudisin B, fumitremorgen B, fusaric acid, 3-hydroxyterphenyllin, ochratoxin alpha, oosporein, penitrem A, physcion, stemphltoxin, verrucosidin, and verruculogen, which were studied with only one in vitro and one bacterial test, and beauvericin and fusarenon $\mathrm{X}$ mycotoxins that were studied using only two different in vitro tests by in vivo testing system for demonstrating genotoxic or mutagenic activity. Among these mycotoxins only oosporein, stemphltoxin, verrucosidin, and beauvericin showed positive results in terms of genotoxic effects, but other mycotoxins showed either negative or unclear/suspicious results (GonzálezPeñas, Vettorazzi, Lizarraga, Azqueta, \& López de Cerain, 2019).

Among the studied mycotoxins, actinomycin D, aflatoxin, alternariol, chrysazin (dantron), citrinin, fumonisin, mytomycin C, nivalenol, ochratoxin A, patulin, sterigmatocystin, versicolorin $\mathrm{A}$ and $\mathrm{B}$, vomitoxin, and zearalenone can be evaluated as genotoxic or mutagenic (Kaynarca, Hecer, \& Ulusoy, 2019).

Acetoscripenol appears to be genotoxic in mouse bone marrow and germ cells, but not in Drosophila wing spot test and bacterial tests. It may have a genotoxic risk due to its effect in in vivo studies in mice. Although averufin, azaserine, cyclosporin A, emodin, girseofulvin, kojic acid, lysergic acid, moniliformin, 3-nitropropionic acid, and T-2 toxins give genotoxically positive results in most tests, additional further tests are required to determine whether they are genotoxic or mutagenic (Bennett \& Klich, 2003). The same matter is applied for chyrsophanol, gliotoxin, luteoskyrin, penicillic acid, PR toxins, rugulosin, secalonic acid D, and sporidesmin, which are negative in most tests because some of the tests that are supposed to be in the test battery are not used in the studies.

\section{Discussion}

Genotoxicity and mutagenicity are terms that are used to describe damage caused by chemicals on chromosome and DNA structure and lead to gene mutations, chromosome abnormalities, and DNA chain breaks. Such mutations can cause foremost congenital defects and many other diseases such as cancer, aging, and infertility. Identification of such effects of chemicals is extremely important in terms of minimizing the frequency of abnormality and disease (Phillips \& Arlt, 2009).

Mutagenicity refers to a chemical or physical agent's capacity to cause mutations (genetic alterations). Agents that damage DNA causing lesions that result in cell death or mutations are genotoxins. All mutagens are genotoxic but not all genotoxins are mutagens as they may not cause retained alterations in DNA sequence (Bełdowski, Been, \& Turmus, 2017)

Of the 109 genotoxically and mutagenically studied mycotoxins, only 14 (actinomycin D, aflatoxin, alternariol, chrysazin (dantron), citrinin, fumonisin, mytomycin C, nivalenol, ochratoxin A, patulin, sterigmatocystin, versicolorin $A$ and $B$, vomitoxin, and zearalenone) were found to be genotoxic. Of the mentioned mycotoxins, aflatoxin, sterigamatocystin and fumonisin are complete animal carcinogens and only aflatoxin is a human carcinogen. There is no sufficient information on the genotoxic and mutagenic effects of the remaining 95 mycotoxins. In particular, additional tests should be performed to detect the genotoxic effects of mycotoxins that are investigated by using only two test systems in case 
of genotoxicity in one of the test systems but nongenotoxicity in the other test system.

When genotoxic studies are performed, application of in vivo tests is especially important because many mycotoxins may show genotoxic effects in in vivo or by being metabolized in the presence of metabolic activators in in vitro. These mycotoxins must undergo biotransformation processes in order to be able to show genotoxicity (Aydın et al., 2017; Bayram, Rencüzoğulları, Almas, \& Genç, 2016; Flajs \& Peraica, 2009; Yourtee \& KirkYourtee, 1986). Wehner, Marasas, \& Thiel (1978a) found out that toxins such as austdiol, austocystins A and D, kojic acid, and viridicatum toxin had mutagenic effects after biotransformation. The same can be said for many other mycotoxins (Wehner, Thiel, van Rensburg, \& Demasius, 1978b).

In some cases, oxidation reactions can expose genotoxicity. Arbillaga Azqueta, Ezpeleta, \& López de Cerain (2007) reported that ochratoxin A is not directly genotoxic; however, oxidative stress in human renal cells affects genotoxicity. It was also found that ochratoxin A enhances radical oxygen production by Russo and colleagues (Russo et al., 2005).

Sometimes in vivo nitrosylation can lead to more severe genotoxic activity. Some studies reported that some alternaria metabolites such as altenuene, alterotoxin I, alternarol, alternarol monomethyl ether, and radicinin mycotoxins have very strong genotoxic effects after nitrosation (Schrader, Cherry, Soper, \& Langlois, 2006; Schrader, Cherry, Soper, Langlois, \& Vijay, 2001).

The chemical structure of mycotoxins or some groups they contain may affect its genotoxic effect. For example, norsoloronic acid, averufin, and versiconal acetate contain anthraquinone. Therefore, their mutagenic effects are weak. However, versicolorin, which is another anthraquinone and contains the bisfuran ring, has high mutagenic activity. Sterigmatocystin also has an anthraquinonedur and xanthone content that contains 2 times more mutagenic effect compared to versicolorin. Aflatoxin B1 contains an anthraquinone and xanthone but the xanthone has been transferred onto a coumarin. This makes aflatoxin B1 10 times more genotoxic (Wong, Singh, \& Hsieh, 1977).

Perhaps the greatest risk for mycotoxins is the combined synergistic effect of multiple mycotoxins. Because many Fusaria can produce more than one mycotoxin at the same time (Scott \& Stoltz, 1980). Aupanun, Poapolathep, Giorgi, Imsilp, \& Poapolathep (2017) showed that some mycotoxins could be present together. It was reported that ochratoxin A and citrinin mycotoxins (Bouslimi, Bouaziz, Ayed-Boussema, Hassen, \& Bacha, 2008) and also cyclopiazonic acid and aflatoxin mycotoxins (Sorenson, Tucker, \& Simpson, 1984) show strong synergistic effects.

One of the greatest risks of mycotoxins is causing cancer. Hsia, Wu, Lu, \& Li (1988) found out that humans eating corn that is contaminated with the trichothecenes group mycotoxins and nivalenol and deoxy-, 3acetyldeoxy, 15-acetyldeoxy derivatives developed esophageal cancers. Brugger et al. (2006) reported that alternariol also causes esophageal cancer. It was also reported that aflatoxin A1 and B1, sterigmatocystin, and luteoskyrin are hepatocarcinogen (Müller, 1987).
Fuminisin was reported to be associated with esophageal cancer as well as with liver cancer in rats (Aranda, PérezAlzola, Ellahueñe, \& Sepúlveda, 2000). Mirsalis, Tyson, \& Butterworth (1982) found out that azaserin is a pancreatic carcinogen.

Some carcinogenic mycotoxins are known to cause cancer through genetic damage. In previous studies, it was reported that mycotoxins that are likely to be genotoxic carcinogens are aflatoxin B1, sterigmatocystin, luteoskyrin, ochratoxin A, azaserine, mitomycin C, and actinomycin D (Beljanski, Le Goff, \& Beljanski, 1982; Hashimoto, Nakajima, Matsumura, \& Chatani, 2010; Mori et al., 1984) and non-genotoxic carcinogens were reported to be penicillic acid, patulin, griseofulvin, and rugulosin (Mori et al., 1984).

Although mitomycin C and actinomycin D are known to be genotoxic carcinogens, these two mycotoxins also have anti-cancer effects due to their direct-acting alkylating agents (Gupta \& Singh, 1982; Parkes \& Scott, $1982)$ and they have also been used as anti-cancer drugs. Similarly, cytochalasin is also a mycotoxin and has antitumor effect (Chang et al., 2016; Chen et al., 2015) because it is a cytokine-blocking agent (Fenech \& Morley, 1985). These chemicals are used as positive mutagenes in genotoxicity studies due to their high genotoxic effects. Duclauxin and danthron have also been reported to be important anticancer compounds (Anisha, Sachidanandan, \& Radhakrishnan, 2018; Fuska, Kuhr, Nemec, \& Fusková, 1974; Kuhr et al., 1973). Therefore, it is also understood that some mycotoxins may be used as anticancer drugs, antibiotics, antibacterials or as medicines for other purposes. Many mycotoxins, such as penicillin, griseofulvin, danthron, emodin, luteoskyrin, cyclochlorotine, rugulosin, rubroskyrin, lumiluteoskyrin, pibasterol, skyrin, cyclosporine, chrysophanol, islandicin, iridoskyrin, fumagillin, and mevinolin (lovastatin) are used as antibiotics or other therapeutic agents (Anisha et al., 2018; Flint, Forsey, \& Usher, 1959; Henninger et al., 2012; Liberman et al., 1980; Mengs, Schuler, \& Marshall, 2001; Mok \& Tey, 2018; Nesslany, Simar-Meintières, Ficheux, \& Marzin, 2009; Sakai et al., 1992; Schafhauser et al., 2016; Stark et al., 1978; Stevanovic, Stanimirovic, Radakovic, \& Stojic, 2008; van den Heever, Thompson, Curtis, \& Pernal, 2015; Yang et al., 2018). Nevertheless, it should not be forgotten that mycotoxins may cause adverse effects in humans such as high blood pressure, headache, kidney problems, increased hair growth, vomiting, liver problems, and increased risk of lymphoma (Cho, Davis, Wetter, Bartley, \& Brewer, 2018; Geller et al., 2018; Ivandić \& Bašić-Jukić, 2014). When mycotoxin is used as a medicine, it will be beneficial for the health of the patient to be under special care.

Mycotoxins, such as alternariol, fusarin, and zearalenone are defined as mycoestrogens. They may cause a number of physiological events in the reproductive tract by exhibiting high estrogenic activity (AyedBoussema, Ouanes, Bacha, \& Abid, 2007). Although some articles state that zearalenone is non-steroidal estrogenic (Pfohl-Leszkowicz, Chekir-Ghedira, \& Bacha, 1995), AbidEssefi et al. (2003) reported that zearalenone increased estrogenic and anabolic properties by binding to human estrogen receptors. It was reported that some mycotoxins may have different effects depending on sexual difference although they are not mycoestrogens. In a genotoxicity study that has been done in male and female mice, it was 
shown that aflatoxin B1 causes higher genotoxic effects in males than females (Madle, Korte, \& Beek, 1986).

\section{Conclusions}

Mycotoxins are toxins that are naturally produced as secondary metabolic products of Fusarium and constitute the greatest risk to humans by causing contaminations in food. Mycotoxins are a large group of toxins that cause various abnormalities in living things, especially cancer, infertility, and congenital defects during pregnancy. Very few of them are known to have genotoxic effects (El Khoury, Fayjaloun, Nassar, Sahakian, \& Aad, 2019). However, the mutation-formation effects of a large part of the remaining mycotoxins have not been investigated. Knowing the genotoxic effects of a mycotoxin ensures the explanation of the disease molecular levels. This is extremely important in terms of reducing the abnormality of the chemistry and the frequency of the disease.

There are also mycotoxins that are used as therapeutics for many diseases, especially antibiotics, and even as anti-cancer drugs. Mycotoxins, which are used as drugs, are biotechnologically produced and purified chemicals. These drugs naturally may give adverse effects and cause some unwanted effects in the living system (Loi, Fanelli, Liuzzi, Logrieco, \& Mulè, 2017).

As a result, since mycotoxins are produced at specific temperature and humidity grades, storage of food in appropriate conditions from the time of production to consumption can reduce mycotoxin contamination. This is extremely important for the protection of human health.

\section{References}

Abd-Allah, G.A., el-Fayoumi, R.I., Smith, M.J., Heckmann, R.A., \& O'Neill, K.L. (1999). A comparative evaluation of aflatoxin B1 genotoxicity in fish models using the Comet assay. Mutation Research, 446(2), 181-188. https:// doi.org/10.1016/s1383-5718(99)00181-3

Abdel-Wahhab, M.A., El-Nekeety, A.A., Salman, A.S., Abdel-Aziem, S.H., Mehaya, F.M., \& Hassan, N.S. (2018). Protective capabilities of silymarin and inulin nanoparticles against hepatic oxidative stress, genotoxicity and cytotoxicity of Deoxynivalenol in rats. Toxicon, 142, 1-13. https://doi.org/10.1016/j.toxicon.2017.12.045

Abid-Essefi, S., Baudrimont, I., Hassen, W., Ouanes, Z., Mobio, T.A., Anane, R., ... Bacha, H. (2003). DNA fragmentation, apoptosis and cell cycle arrest induced by zearalenone in cultured DOK, Vero and Caco- 2 cells: Prevention by Vitamin E. Toxicology, 192(2-3), 237-248. https://doi.org/10.1016/s0300-483x(03)00329-9

Aichinger, G., Beisl, J., \& Marko, D. (2017). Genistein and delphinidin antagonize the genotoxic effects of the mycotoxin alternariol in human colon carcinoma cells. Molecular Nutrition \& Food Research, 61(2). https://doi.org/10.1002/mnfr.201600462

Alarcón-Herrera, N., Flores-Maya, S., Bellido, B., García-Bores, A. M., Mendoza, E., Ávila-Acevedo, G., \& Hernández-Echeagaray, E. (2017). Protective effects of chlorogenic acid in 3-nitropropionic acid induced toxicity and genotoxicity. Food and Chemical Toxicology, 109(2), 10181025. https://doi.org/10.1016/i.fct.2017.04.048

Albertini, R.J., Anderson, D., Douglas, G.R., Hagmar, L., Hemminki, K., Merlo, F., ... Aitio, A. (2000). IPCS guidelines for the monitoring of genotoxic effects of carcinogens in humans. International Programme on Chemical Safety. Mutation Research, 463(2), 111-172. https://doi.org/10.1016/s1383-5742(00)00049-1

Aleksic, B., Draghi, M., Ritoux, S., Bailly, S., Lacroix, M., Oswald, I.P., ... Robine, E. (2017). Aerosolization of mycotoxins after growth of toxinogenic fungi on wallpaper. Applied and Environmental Microbiology, 83(16). https://doi.org/10.1128/AEM.01001-17

Ali, R., Guo, X., Lin, H., Khan, Q.M., Ismail, M., Waheed, U., ... Bhalli, J.A. (2014). Mutant frequency in comparison to oxidative DNA damage induced by ochratoxin A in L5178Y tk+/- (3.7.2C) mouse lymphoma cells. Drug and Chemical Toxicology, 37(2), 227-232. https:// doi.org/10.3109/01480545.2013.838775

Ali, R., Mittelstaedt, R.A., Shaddock, J.G., Ding, W., Bhalli, J.A., Khan, Q.M., \& Heflich, R.H. (2011). Comparative analysis of micronuclei and DNA damage induced by Ochratoxin A in two mammalian cell lines.
Mutation Research, 723(1),

$58-64$.

https:// doi.org/10.1016/j.mrgentox.2011.04.002

Alves, I., Oliveira, N.G., Laires, A., Rodrigues, A.S., \& Rueff, J. (2000) Induction of micronuclei and chromosomal aberrations by the mycotoxin patulin in mammalian cells: Role of ascorbic acid as a modulator of patulin clastogenicity. Mutagenesis, 15(3), 229-234. https://doi.org/10.1093/mutage/15.3.229

Anisha, C., Sachidanandan, P., \& Radhakrishnan, E.K. (2018). Endophytic Paraconiothyrium sp. from zingiber officinale rosc. displays broadspectrum antimicrobial activity by production of danthron. Current Microbiology, 75(3), 343-352. https:// doi.org/10.1007/s00284-017-1387$\underline{7}$

Anninou, N., Chatzaki, E., Papachristou, F., Pitiakoudis, M., \& Simopoulos, C. (2014). Mycotoxins' activity at toxic and sub-toxic concentrations: Differential cytotoxic and genotoxic effects of single and combined administration of sterigmatocystin, ochratoxin A and citrinin on the hepatocellular cancer cell line Hep3B. International Journal of Environmental Research and Public Health, 11(2), 1855-1872. https://doi.org/10.3390/ijerph110201855

Aoyama, K., Iwahori, K., \& Miyata, N. (2003). Application of Euglena gracilis cells to comet assay: Evaluation of DNA damage and repair. Mutation Research, 538(1-2), 155-162. https://doi.org/10.1016/s13835718(03)00113-x

Aranda, M., Pérez-Alzola, L.P., Ellahueñe, M.F., \& Sepúlveda, C. (2000). Assessment of in vitro mutagenicity in Salmonella and in vivo genotoxicity in mice of the mycotoxin fumonisin $\mathrm{B}(1)$. Mutagenesis, 15(6), 469-471. https:// doi.org/10.1093/mutage/15.6.469

Arbillaga, L., Azqueta, A., Ezpeleta, O., \& López de Cerain, A. (2007). Oxidative DNA damage induced by Ochratoxin A in the HK-2 human kidney cell line: Evidence of the relationship with cytotoxicity. Mutagenesis, 22(1), 35-42. https://doi.org/10.1093/mutage/gel049

Atherton, G, \& Betb, B. (2019). Secondary metabolites. Retrieved from http://www.aspergillus.org.uk/metabolite-images/secondarymetabolites

Atienzar, F.A., \& Jha, A.N. (2006). The random amplified polymorphic DNA (RAPD) assay and related techniques applied to genotoxicity and carcinogenesis studies: A critical review. Mutation Research, 613(2-3), 76-102. https:// doi.org/10.1016/i.mrrev.2006.06.001

Atienzar, F.A., Cordi, B., Donkin, M.E., Evenden, A.J., Jha, A.N., \& Depledge, M.H. (2000). Comparison of ultraviolet-induced genotoxicity detected by random amplified polymorphic DNA with chlorophyll fluorescence and growth in a marine macroalgae, Palmaria palmata. Aquatic Toxicology, 50(1), 1-12. https://doi.org/10.1016/S0166445X(99)00100-9

Auffray, Y., \& Boutibonnes, P. (1987). Genotoxic activity of some mycotoxins using the SOS chromotest. Mycopathologia, 100(1), 49-53. https://doi.org/10.1007/BF00769568

Aupanun, S., Poapolathep, S., Giorgi, M., Imsilp, K., \& Poapolathep, A (2017). An overview of the toxicology and toxicokinetics of fusarenonX, a type B trichothecene mycotoxin. The Journal of Veterinary Medical Science, 79(1), 6-13. https:// doi.org/10.1292/jvms.16-0008

Awad, W.A., Ghareeb, K., Dadak, A., Gille, L., Staniek, K., Hess, M., \& Böhm, J. (2012). Genotoxic effects of deoxynivalenol in broiler chickens fed low-protein feeds. Poultry Science, 91(3), 550-555. https://doi.org/10.3382/ps.2011-01742

Awad, Wageha A., Ghareeb, K., Dadak, A., Hess, M., \& Böhm, J. (2014). Single and combined effects of deoxynivalenol mycotoxin and a microbial feed additive on lymphocyte DNA damage and oxidative stress in broiler chickens. PLOS ONE, 9(1), e88028. https://doi.org/10.1371/journal.pone.0088028

Aydın, M., Arslan, M., Rencüzoğulları, E., Gözaydın, C., Genç, A., \& Bayram, S. (2017). Investigation of XRCC1 Arg399Gln, Arg280His, and Arg194Trp polymorphisms effects on the induction of micronucleus by Aflatoxin B1 in in vitro. Gene Reports, 9, 1-6. https://doi.org/10.1016/i.genrep.2017.08.002

Ayed-Boussema, I., Ouanes, Z., Bacha, H., \& Abid, S. (2007). Toxicities induced in cultured cells exposed to zearalenone: Apoptosis or mutagenesis? Journal of Biochemical and Molecular Toxicology, 21(3), 136144. https:// doi.org/10.1002/jbt.20171

Ayed, Y., Ayed-Boussema, I., Ouanes, Z., \& Bacha, H. (2011). In vitro and in vivo induction of chromosome aberrations by alpha- and betazearalenols: Comparison with zearalenone. Mutation Research, 726(1), 42-46. https:// doi.org/10.1016/i.mrgentox.2011.08.003

Banerjee, S., \& Paruthy, S.B. (2016). Preclinical and clinical perspective on fungal metabolites and their analogs as anticancer agents - from bench to bedside. In J.M. Mérillon \& K.G. Ramawat (Eds.), Fungal Metabolites (pp. 1-32). https://doi.org/10.1007/978-3-319-19456-1_22-1

Bartholomew, R.M., \& Ryan, D.S. (1980). Lack of mutagenicity of some phytoestrogens in the Salmonella/mammalian microsome assay. 
Mutation Research, 78(4), 317-321. https://doi.org/10.1016/01651218(80)90036-1

Batiste-Alentorn, M., Xamena, N., Creus, A., \& Marcos, R. (1995). Genotoxicity testing of five compounds in three Drosophila short-term somatic assays. Mutation Research, 341(3), 161-167. https://doi.org/10.1016/0165-1218(95)90006-3

Bayram, S., Rencüzoğulları, E., Almas, A.M., \& Genç, A. (2016). Effect of p53 Arg72Pro polymorphism on the induction of micronucleus by aflatoxin B1 in in vitro in human blood lymphocytes. Drug and Chemical Toxicology, 39(3),

331-337. https:/ / doi.org/10.3109/01480545.2015.1121275

Becerril, C., Ferrero, M., Sanz, F., \& Castaño, A. (1999). Detection of mitomycin C-induced genetic damage in fish cells by use of RAPD. Mutagenesis, 14(5), 449-456. https:/ / doi.org/10.1093/mutage/14.5.449

Behm, C., Degen, G.H., \& Föllmann, W. (2009). The Fusarium toxin enniatin B exerts no genotoxic activity, but pronounced cytotoxicity in vitro. Molecular Nutrition \& Food Research, 53(4), 423-430. https://doi.org/10.1002/mnfr.200800183

Bełdowski, J., Been, R., \& Turmus, E.K. (2017). Towards the Monitoring of Dumped Munitions Threat (MODUM): A Study of Chemical Munitions Dumpsites in the Baltic Sea. Dordrecht, The Netherlands, Springer.

Beljanski, M., Le Goff, L., \& Beljanski, M. (1982). In vitro screening of carcinogens using DNA of the His- mutant of Salmonella typhimurium. Experimental Cell Biology, 50(5), 271-280.

Bendele, A.M., Neal, S.B., Oberly, T.J., Thompson, C.Z., Bewsey, B.J., Hill, L.E., ... Probst, G.S. (1985). Evaluation of ochratoxin A for mutagenicity in a battery of bacterial and mammalian cell assays. Food and Chemical Toxicology, 23(10), 911-918. $\quad$ https://doi.org/10.1016/02786915(85)90107-3

Benedict, W.F., Baker, M.S., Haroun, L., Choi, E., \& Ames, B.N. (1977). Mutagenicity of cancer chemotherapeutic agents in the Salmonella/microsome test. Cancer Research, 37(7 Pt 1), 2209-2213.

Bennett, J.W. \& Klich, M. (2003). Mycotoxins. Clinical Microbiology Reviews, 16(3), 497-516.

Bensassi, F., El Golli-Bennour, E., Abid-Essefi, S., Bouaziz, C., Hajlaoui, M.R., \& Bacha, H. (2009). Pathway of deoxynivalenol-induced apoptosis in human colon carcinoma cells. Toxicology, 264(1-2), 104-109. https://doi.org/10.1016/j.tox.2009.07.020

Bhat, P.V., Pandareesh, M.D., Khanum, F., \& Tamatam, A. (2016). Cytotoxic Effects of Ochratoxin A in Neuro-2a Cells: Role of Oxidative Stress Evidenced by $\mathrm{N}$-acetylcysteine. Frontiers in Microbiology, 7, 1142. https:// doi.org/10.3389/fmicb.2016.01142

Bjeldanes, L.F., \& Chew, H. (1979). Mutagenicity of 1,2-dicarbonyl compounds: Maltol, kojic acid, diacetyl and related substances. Mutation Research, 67(4), 367-371. https://doi.org/10.1016/01651218(79)90034-X

Blanc, P.J., Laussac, J.P., Le Bars, J., Le Bars, P., Loret, M.O., Pareilleux, A., ... Goma, G. (1995). Characterization of monascidin A from Monascus as citrinin. International Journal of Food Microbiology, 27(2-3), 201-213. https:// doi.org/10.1016/0168-1605(94)00167-5

Bonassi, S., Hagmar, L., Strömberg, U., Montagud, A.H., Tinnerberg, H., Forni, A., ... Norppa, H. (2000). Chromosomal aberrations in lymphocytes predict human cancer independently of exposure to carcinogens. European Study Group on Cytogenetic Biomarkers and Health. Cancer Research, 60(6), 1619-1625.

Bonassi, S., Ugolini, D., Kirsch-Volders, M., Strömberg, U., Vermeulen, R., \& Tucker, J.D. (2005). Human population studies with cytogenetic biomarkers: Review of the literature and future prospectives. Environmental and Molecular Mutagenesis, 45(2-3), 258-270. https://doi.org/10.1002/em.20115

Bonassi, S., Znaor, A., Ceppi, M., Lando, C., Chang, W.P., Holland, N., Fenech, M. (2007). An increased micronucleus frequency in peripheral blood lymphocytes predicts the risk of cancer in humans. Carcinogenesis, 28(3), 625-631. https:/ / doi.org/10.1093/carcin/bgl177

Bonassi, S., Znaor, A., Norppa, H., \& Hagmar, L. (2004). Chromosomal aberrations and risk of cancer in humans: An epidemiologic perspective. Cytogenetic and Genome Research, 104(1-4), 376-382. https://doi.org/10.1159/000077519

Bony, S., Carcelen, M., Olivier, L., \& Devaux, A. (2006). Genotoxicity assessment of deoxynivalenol in the Caco-2 cell line model using the Comet assay. Toxicology Letters, 166(1), 67-76. https://doi.org/10.1016/j.toxlet.2006.04.010

Bony, S., Olivier-Loiseau, L., Carcelen, M., \& Devaux, A. (2007). Genotoxic potential associated with low levels of the Fusarium mycotoxins nivalenol and fusarenon $\mathrm{X}$ in a human intestinal cell line. Toxicology in vitro: An International Journal Published in Association with BIBRA, 21(3), 457-465. https://doi.org/10.1016/j.tiv.2006.10.014

Bosio, P., Siciliano, I., Gilardi, G., Gullino, M., \& Garibaldi, A. (2017). Verrucarin A and roridin E produced on rocket by Myrothecium roridum under different temperatures and $\mathrm{CO} 2$ levels. World Mycotoxin Journal, 10(3), 229-236. https:/ / doi.org/10.3920/WMJ2017.2198

Bouslimi, A., Bouaziz, C., Ayed-Boussema, I., Hassen, W., \& Bacha, H. (2008). Individual and combined effects of ochratoxin A and citrinin on viability and DNA fragmentation in cultured Vero cells and on chromosome aberrations in mice bone marrow cells. Toxicology, 251(13), 1-7. https://doi.org/10.1016/i.tox.2008.06.008

Brkanac, S.R., Gerić, M., Gajski, G., Vujčić, V., Garaj-Vrhovac, V., Kremer, D., \& Domijan, A.M. (2015). Toxicity and antioxidant capacity of Frangula alnus Mill. Bark and its active component emodin. Regulatory Toxicology and Pharmacology: RTP, 73(3), 923-929. https://doi.org/10.1016/i.yrtph.2015.09.025

Browning, L.S. (1968). Lysergic acid diethylamine: Mutagenic effects in Drosophila. Science (New York, N.Y.), 161(3845), 1022-1023. https://doi.org/10.1126/science.161.3845.1022

Brugger, E.M., Wagner, J., Schumacher, D.M., Koch, K., Podlech, J., Metzler, M., \& Lehmann, L. (2006). Mutagenicity of the mycotoxin alternariol in cultured mammalian cells. Toxicology Letters, 164(3), 221-230. https:// doi.org/10.1016/j.toxlet.2006.01.001

Carrano, A.V., \& Natarajan, A.T. (1988). Considerations for population monitoring using cytogenetic techniques. Mutation Research, 204(3), 379-406. https:/ / doi.org/10.1016/0165-1218(88)90036-5

Carrano, A.V., Thompson, L.H., Lindl, P.A., \& Minkler, J.L. (1978). Sister chromatid exchange as an indicator of mutagenesis. Nature, 271(5645), 551-553. https://doi.org/10.1038/271551a0

Celik, M., Aksoy, H., \& Yilmaz, S. (2010). Evaluation of beauvericin genotoxicity with the chromosomal aberrations, sister-chromatid exchanges and micronucleus assays. Ecotoxicology and Environmental Safety, 73(7), 1553-1557. https:// doi.org/10.1016/i.ecoenv.2010.07.036

Celik, M., Yilmaz, S., Aksoy, H., Unal, F., Yüzbaşioğlu, D., \& Dönbak, L. (2009). Evaluation of the genotoxicity of Fusarium mycotoxin moniliformin in human peripheral blood lymphocytes. Environmental and Molecular Mutagenesis, 50(5), 431-434. https://doi.org/10.1002/em.20459

Chagas, F.O., Dias, L.G., \& Pupo, M.T. (2013). A mixed culture of endophytic fungi increases production of antifungal polyketides. Journal of Chemical Ecology, 39(10), 1335-1342. https:// doi.org/10.1007/s10886-013-0351-7

Chang, H.T., Chou, C.T., Chen, I.S., Yu, C.C., Lu, T., Hsu, S.S., ... Liang, W.Z. (2016). Mechanisms underlying effect of the mycotoxin cytochalasin B on induction of cytotoxicity, modulation of cell cycle, $\mathrm{Ca} 2+$ homeostasis and ROS production in human breast cells. Toxicology, 370, 1-19. https:// doi.org/10.1016/j.tox.2016.09.006

Chen, C., Wang, J., Liu, J., Zhu, H., Sun, B., Wang, J., ... Zhang, Y. (2015). Armochaetoglobins A-J: Cytochalasan Alkaloids from Chaetomium globosum TW1-1, a Fungus derived from the terrestrial arthropod Armadillidium vulgare. Journal of Natural Products, 78(6), 1193-1201. https://doi.org/10.1021/np500626x

Chen, Y.Y., Chiang, S.Y., Lin, J.G., Yang, J.S., Ma, Y.S., Liao, C.L., ... Chung J.G. (2010). Emodin, aloe-emodin and rhein induced DNA damage and inhibited DNA repair gene expression in SCC-4 human tongue cancer cells. Anticancer Research, 30(3), 945-951.

Cheng, T.J., Christiani, D.C., Xu, X., Wain, J.C., Wiencke, J.K., \& Kelsey, K.T. (1996). Increased micronucleus frequency in lymphocytes from smokers with lung cancer. Mutation Research, 349(1), 43-50. https://doi.org/10.1016/0027-5107(95)00150-6

Cho, J.M., Davis, D.M.R., Wetter, D.A., Bartley, A.C., \& Brewer, J.D. (2018). Association between atopic dermatitis and squamous cell carcinoma: A case-control study. International Journal of Dermatology, 57(3), 313-316. https://doi.org/10.1111/ijd.13857

Cilião, H.L., Ribeiro, D.L., Camargo-Godoy, R.B.O., Specian, A.F.L., Serpeloni, J.M., \& Cólus, I.M.S. (2015). Cytotoxic and genotoxic effects of high concentrations of the immunosuppressive drugs cyclosporine and tacrolimus in MRC-5 cells. Experimental and Toxicologic Pathology: Official Journal of the Gesellschaft Fur Toxikologische Pathologie, 67(2), 179187. https://doi.org/10.1016/i.etp.2014.11.008

Cohen, M.M., Marinello, M.J., \& Back, N. (1967). Chromosomal damage in human leukocytes induced by lysergic acid diethylamide. Science (New York, N.Y.), 155(3768), https:// doi.org/10.1126/science.155.3768.1417

Cole, R.J., Taylor, N., Cole, J., \& Arlett, C.F. (1981). Short-term tests for transplacentally active carcinogens: I. Micronucleus formation in fetal and maternal mouse erythroblasts. Mutation Research, 80(1), 141-157. https://doi.org/10.1016/0027-5107(81)90184-6

Corcuera, L.A., Vettorazzi, A., Arbillaga, L., Pérez, N., Gil, A. G., Azqueta A., ... López de Cerain, A. (2015). Genotoxicity of Aflatoxin B1 and Ochratoxin A after simultaneous application of the in vivo micronucleus and comet assay. Food and Chemical Toxicology, 76, 116-124. https:// doi.org/10.1016/j.fct.2014.12.003 
Costa, J.G., Saraiva, N., Guerreiro, P.S., Louro, H., Silva, M.J., Miranda, J.P., Oliveira, N.G. (2016). Ochratoxin A-induced cytotoxicity, genotoxicity and reactive oxygen species in kidney cells: An integrative approach of complementary endpoints. Food and Chemical Toxicology, 87, 65-76. https://doi.org/10.1016/i.fct.2015.11.018

Crebelli, R., Carere, A., Conti, G., Conti, L., Rossi, C., \& Tuttobello, L. (1988). Evaluation of the mutagenic activity of leucinostatins, a novel class of antibiotic peptides produced by Paecilomyces marquandii, in the modul Aspergillus nidulans. Microbiologica, 11(4), 299-305.

Creppy, E.E., Kane, A., Dirheimer, G., Lafarge-Frayssinet, C., Mousset, S., \& Frayssinet, C. (1985). Genotoxicity of ochratoxin a in mice: DNA single-strand break evaluation in spleen, liver and kidney. Toxicology Letters, 28(1), 29-35. https:// doi.org/10.1016/0378-4274(85)90006-2

Curry, P.T., Reed, R.N., Martino, R.M., \& Kitchin, R.M. (1984). Induction of sister-chromatid exchanges in vivo in mice by the mycotoxins sterigmatocystin and griseofulvin. Mutation Research, 137(2-3), 111-115. https://doi.org/10.1016/0165-1218(84)90099-5

Davis, V.M., \& Stack, M.E. (1991). Mutagenicity of stemphyltoxin III, a metabolite of Alternaria alternata. Applied and Environmental Microbiology, 57(1), 180-182.

de Melo, F.T., de Oliveira, I.M., Greggio, S., Dacosta, J.C., Guecheva, T.N., Saffi, J., ... Rosa, R.M. (2012). DNA damage in organs of mice treated acutely with patulin, a known mycotoxin. Food and Chemical Toxicology, 50(10), 3548-3555. https:// doi.org/10.1016/j.fct.2011.12.022

De Wolf, H., Blust, R., \& Backeljau, T. (2004). The population genetic structure of Littorina littorea (Mollusca: Gastropoda) along a pollution gradient in the Scheldt estuary (The Netherlands) using RAPD analysis. The Science of the Total Environment, 325(1-3), 59-69. https://doi.org/10.1016/i.scitotenv.2003.11.004

Dean, R., Bynum, G., Kram, D., \& Schneider, E.L. (1980). Sister-chromatid exchange induction by carcinogens in HTC cells: An in vitro system which does not require addition of activating factors. Mutation Research, 74(6), 477-483. https:/ / doi.org/10.1016/0165-1161(80)90178-8

Degen, G.H., Lebrun, S., Lektarau, Y., \& Föllmann, W. (2005). Modulation of ochratoxin A induced DNA-damage in urothelial cell cultures. Mycotoxin Research, 21(1), 57-60. https:/ / doi.org/10.1007/BF02954819

Dellarco, V.L., Mavournin, K.H., \& Tice, R.R. (1985). Aneuploidy and health risk assessment: Current status and future directions. Environmental Mutagenesis, 7(3), 405-424. https://doi.org/10.1002/em.2860070314

DeMarini, D.M., Brock, K.H., Doerr, C.L., \& Moore, M.M. (1987). Mutagenicity of actinomycin D in mammalian cells due to clastogenic effects. Mutation Research, 192(2), 151-155. https:// doi.org/10.1016/0165-7992(87)90113-8

Devnarain, N., Tiloke, C., Nagiah, S., \& Chuturgoon, A.A. (2017). Fusaric acid induces oxidative stress and apoptosis in human cancerous oesophageal SNO cells. Toxicon, 126, 4-11. https://doi.org/10.1016/j.toxicon.2016.12.006

Domijan, A.M., Gajski, G., Novak Jovanović, I., Gerić, M., \& Garaj-Vrhovac, V. (2015). In vitro genotoxicity of mycotoxins ochratoxin A and fumonisin $\mathrm{B}(1)$ could be prevented by sodium copper chlorophyllinImplication to their genotoxic mechanism. Food Chemistry, 170, 455-462. https://doi.org/10.1016/j.foodchem.2014.08.036

Domijan, A.M., Zeljezić, D., Kopjar, N., \& Peraica, M. (2006). Standard and Fpg-modified comet assay in kidney cells of ochratoxin A- and fumonisin $\mathrm{B}(1)$-treated rats. Toxicology, 222(1-2), 53-59. https://doi.org/10.1016/j.tox.2006.01.024

Domijan, A.M., Zeljezić, D., Milić, M., \& Peraica, M. (2007). Fumonisin B(1): Oxidative status and DNA damage in rats. Toxicology, 232(3), 163-169. https://doi.org/10.1016/j.tox.2007.01.007

Donmez-Altuntas, H., Gokalp-Yildiz, P., Bitgen, N., \& Hamurcu, Z. (2013). Evaluation of genotoxicity, cytotoxicity and cytostasis in human lymphocytes exposed to patulin by using the cytokinesis-block micronucleus cytome (CBMN cyt) assay. Mycotoxin Research, 29(2), 63 70. https://doi.org/10.1007/s12550-012-0153-8

Dönmez-Altuntas, H., Dumlupinar, G., Imamoglu, N., Hamurcu, Z., \& Liman, B.C. (2007). Effects of the mycotoxin citrinin on micronucleus formation in a cytokinesis-block genotoxicity assay in cultured human lymphocytes. Journal of Applied Toxicology: JAT, 27(4), 337-341. https://doi.org/10.1002/jat.1209

Dönmez-Altuntaş, H., Hamurcu, Z., Imamoglu, N., \& Liman, B.C. (2003). Effects of ochratoxin A on micronucleus frequency in human

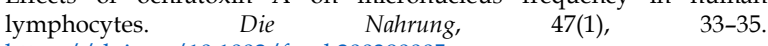
https://doi.org/10.1002/food.200390005

Dörrenhaus, A., Flieger, A., Golka, K., Schulze, H., Albrecht, M., Degen, G.H., \& Föllmann, W. (2000). Induction of unscheduled DNA synthesis in primary human urothelial cells by the mycotoxin ochratoxin A. Toxicological Sciences: An Official Journal of the Society of Toxicology, 53(2), 271-277. https:// doi.org/10.1093/toxsci/53.2.271
Duffaud, F., Orsière, T., Villani, P., Pelissier, A.L., Volot, F., Favre, R., \& Botta, A. (1997). Comparison between micronucleated lymphocyte rates observed in healthy subjects and cancer patients. Mutagenesis, 12(4), 227-231. https:// doi.org/10.1093/mutage/12.4.227

EFSA (2011). Opinion on genotoxicity testing strategies. Retrieved December 5, 2019, from European Food Safety Authority website: https://www.efsa.europa.eu/en/efsajournal/pub/2379

EFSA. (2017). Clarification of some aspects related to genotoxicity assessment. (2017, December 18). Retrieved December 5, 2019, from European Food Safety Authority website: https://www.efsa.europa.eu/en/efsajournal/pub/5113

Ehrlich, V., Darroudi, F., Uhl, M., Steinkellner, H., Gann, M., Majer, B.J., ... Knasmüller, S. (2002a). Genotoxic effects of ochratoxin A in humanderived hepatoma (HepG2) cells. Food and Chemical Toxicology, 40(8), 1085-1090. https://doi.org/10.1016/S0278-6915(02)00045-5

Ehrlich, V., Darroudi, F., Uhl, M., Steinkellner, H., Zsivkovits, M., \& Knasmueller, S. (2002b). Fumonisin B1 is genotoxic in human derived hepatoma (HepG2) cells. Mutagenesis, 17(3), 257-260. https://doi.org/10.1093/mutage/17.3.257

El. Khoury, D., Fayjaloun, S., Nassar, M., Sahakian, J., \& Aad, P.Y. (2019). Updates on the effect of mycotoxins on male reproductive efficiency in mammals. Toxins, 11(9). https:/ / doi.org/10.3390/toxins11090515

Escrivá, L., Font, G., \& Manyes, L. (2015). In vivo toxicity studies of fusarium mycotoxins in the last decade: A review. Food and Chemical Toxicology, 78, 185-206. https:// doi.org/10.1016/j.fct.2015.02.005

Estop, A.M., Cieply, K., Vankirk, V., Munne, S., \& Garver, K. (1991). Cytogenetic studies in human sperm. Human Genetics, 87(4), 447-451. https://doi.org/10.1007/BF00197166

Evans, H.J. (1984). Human Peripheral Blood Lymphocytes for the Analysis of Chromosome Aberrations in Mutagen Tests. In: Kilbey BJ, Legator M, Nichols W, Ramel C (eds) Handbook of Mutagenicity Test Procedures, $2^{\text {nd }}$ ed. Elsevier Sci BV, pp. 405-427.

Evans, H.J., \& O'Riordan, M.L. (1975). Human peripheral blood lymphocytes for the analysis of chromosome aberrations in mutagen tests. Mutation Research, 31(3), 135-148. https:// doi.org/10.1016/0165$\underline{1161(75) 90082-5}$

Fabian, D., Rehák, P., Czikková, S., Il'ková, G., Baran, V., \& Koppel, J. (2003). Induced cell death of preimplantation mouse embryos cultured in vitro evaluated by comet assay. Theriogenology, 60(4), 691-706. https:// doi.org/10.1016/s0093-691x(03)00087-6

Fahmy, M.A., \& Hassan, N.H. (1996). Cytogenetic effect of griseofulvin in mouse spermatocytes. Journal of Applied Toxicology: JAT, 16(2), 177-183. https://doi.org/10.1002/(SICI)1099-1263(199603)16:2<177::AIDJAT330>3.0.CO;2-T

Fenech, M., \& Morley, A.A. (1985). Measurement of micronuclei in lymphocytes. Mutation Research, 147(1-2), 29-36. https://doi.org/10.1016/0165-1161(85)90015-9

Fenech, M., Holland, N., Chang, W.P., Zeiger, E., \& Bonassi, S. (1999). The HUman MicroNucleus Project-An international collaborative study on the use of the micronucleus technique for measuring DNA damage in humans. Mutation Research, 428(1-2), 271-283. https:// doi.org/10.1016/s1383-5742(99)00053-8

Fenech, M.. (2002). Biomarkers of genetic damage for cancer epidemiology. Toxicology, 181-182, 411-416. https://doi.org/10.1016/s0300$\underline{483 \times(02) 00480-8}$

Ferguson, L.R., Berriman, J., Pearson, A., Munday, R., Fowke, E.A., \& Towers, N.R. (1992). In vitro and in vivo mutagenicity studies on sporidesmin, the toxin associated with facial eczema in ruminants. Mutation Research, 268(2), 199-210. https://doi.org/10.1016/0027$\underline{5107(92) 90225-\mathrm{q}}$

Fernández-Blanco, C., Font, G., \& Ruiz, M.J. (2015). Oxidative DNA damage and disturbance of antioxidant capacity by alternariol in Caco-2 cells. $\begin{array}{lll}\text { Toxicology Letters, } & \text { 235(2), 61-66. }\end{array}$ https:/ / doi.org/10.1016/i.toxlet.2015.03.013

Ferrero, M., Castaño, A., Gonzalez, A., Sanz, F., \& Becerril, C. (1998). Characterization of RTG-2 fish cell line by random amplified polymorphic DNA. Ecotoxicology and Environmental Safety, 40(1-2), 5664. https://doi.org/10.1006/eesa.1998.1642

Fisher, C.R., Malling, H.V., De Serres, F.J., \& Snyder, S. (1975). Mutagenicity of actinomycin D in Neurospora crassa. Mutation Research, 33(2-3), 187192. https://doi.org/10.1016/0027-5107(75)90194-3

Flajs, D., \& Peraica, M. (2009). Toxicological properties of citrinin. Arhiv Za Higijenu Rada I Toksikologiju, 60(4), 457-464. https://doi.org/10.2478/10004-1254-60-2009-1992

Fleck, S.C., Burkhardt, B., Pfeiffer, E., \& Metzler, M. (2012). Alternaria toxins: Altertoxin II is a much stronger mutagen and DNA strand breaking mycotoxin than alternariol and its methyl ether in cultured mammalian cells. Toxicology Letters, 214(1), 27-32. https://doi.org/10.1016/j.toxlet.2012.08.003 
Fleck, S.C., Sauter, F., Pfeiffer, E., Metzler, M., Hartwig, A., \& Köberle, B. (2016). DNA damage and repair kinetics of the Alternaria mycotoxins alternariol, altertoxin II and stemphyltoxin III in cultured cells. Mutation Research, 798-799, https://doi.org/10.1016/j.mrgentox.2016.02.001

Flint, A., Forsey, R.R., \& Usher, B. (1959). Griseofulvin, a new oral antibiotic for the treatment of fungous infections of the skin. Canadian Medical Association Journal, 81(3), 173-175.

Föllmann, W., \& Lebrun, S. (2003). Uptake and genotoxic effects of ochratoxin A in cultured porcine urinary bladder epithelial cells. Mycotoxin Research, 19(1), 24-26. https:// doi.org/10.1007/BF02940086

Föllmann, W., Behm, C., \& Degen, G.H. (2007). Induction of micronuclei by ochratoxin $\mathrm{A}$ is a sensitive parameter of its genotoxicity in cultured cells. Mycotoxin Research, 23(2), 101. https://doi.org/10.1007/BF02946034

Föllmann, W., Hillebrand, I.E., Creppy, E.E., \& Bolt, H.M. (1995). Sister chromatid exchange frequency in cultured isolated porcine urinary bladder epithelial cells (PUBEC) treated with ochratoxin A and alpha. $\begin{array}{llll}\text { Archives of Toxicology, 69(4), 280-286. } & \end{array}$ https://doi.org/10.1007/s002040050171

Föllmann, Wolfram, Behm, C., \& Degen, G.H. (2009). The emerging Fusarium toxin enniatin B: In vitro studies on its genotoxic potential and cytotoxicity in V79 cells in relation to other mycotoxins. Mycotoxin Research, 25(1), 11-19. https:/ / doi.org/10.1007/s12550-008-0002-y

Frankic, T., Pajk, T., Rezar, V., Levart, A., \& Salobir, J. (2006). The role of dietary nucleotides in reduction of DNA damage induced by T-2 toxin and deoxynivalenol in chicken leukocytes. Food and Chemical Toxicology, 44(11), 1838-1844. https://doi.org/10.1016/j.fct.2006.06.002

Frenzilli, G., Bosco, E., \& Barale, R. (2000). Validation of single cell gel assay in human leukocytes with 18 reference compounds. Mutation Research, 468(2), 93-108. https://doi.org/10.1016/S1383-5718(00)00042-5

Fuska, J., Kuhr, I., Nemec, P., \& Fusková, A. (1974). Antitumor antibiotics produced by Penicillium stipitatum Thom. The Journal of Antibiotics, 27(2), 123-127. https://doi.org/10.7164/antibiotics.27.123

Galvano, F., Campisi, A., Russo, A., Galvano, G., Palumbo, M., Renis, M., ... Vanella, A. (2002a). DNA damage in astrocytes exposed to fumonisin B1. Neurochemical Research, 27(4), 345-351. https://doi.org/10.1023/a:1014971515377

Galvano, F., Russo, A., Cardile, V., Galvano, G., Vanella, A., \& Renis, M. (2002b). DNA damage in human fibroblasts exposed to fumonisin B(1). Food and Chemical Toxicology, 40(1), 25-31. https://doi.org/10.1016/s0278-6915(01)00083-7

Gao, F., Jiang, L., Chen, M., Geng, C., Yang, G., Ji, F., ... Liu, X. (2013). Genotoxic effects induced by zearalenone in a human embryonic kidney cell line. Mutation Research, 755(1), 6-10. https://doi.org/10.1016/i.mrgentox.2013.04.009

Gao, W., Jiang, L., Ge, L., Chen, M., Geng, C., Yang, G., ... Liu, X. (2015). Sterigmatocystin-induced oxidative DNA damage in human liverderived cell line through lysosomal damage. Toxicology in Vitro: An International Journal Published in Association with BIBRA, 29(1), 1-7. https://doi.org/10.1016/j.tiv.2014.08.007

Geller, S., Xu, H., Lebwohl, M., Nardone, B., Lacouture, M.E., \& Kheterpal, M. (2018). Malignancy Risk and Recurrence with Psoriasis and its Treatments: A Concise Update. American Journal of Clinical Dermatology, 19(3), 363-375. https://doi.org/10.1007/s40257-017-0337-2

Ghaderi, M., Allameh, A., Soleimani, M., Rastegar, H., \& Ahmadi-Ashtiani, H.R. (2011). A comparison of DNA damage induced by aflatoxin B1 in hepatocyte-like cells, their progenitor mesenchymal stem cells and CD34(+) cells isolated from umbilical cord blood. Mutation Research, 719(1-2), 14-20. https:// doi.org/10.1016/j.mrgentox.2010.09.005

Ghazi, T., Nagiah, S., Tiloke, C., Sheik Abdul, N., \& Chuturgoon, A.A. (2017). Fusaric Acid Induces DNA Damage and Post-Translational Modifications of p53 in Human Hepatocellular Carcinoma (HepG2) Cells. Journal of Cellular Biochemistry, 118(11), 3866-3874. https://doi.org/10.1002/jcb.26037

Ghédira-Chékir, L., Maaroufi, K., Zakhama, A., Ellouz, F., Dhouib, S., Creppy, E.E., \& Bacha, H. (1998). Induction of a SOS repair system in lysogenic bacteria by zearalenone and its prevention by vitamin $\mathrm{E}$. Chemico-Biological Interactions, 113(1), 15-25. https:// doi.org/10.1016/s0009-2797(98)00013-1

Glatt, H., Eich, E., Pertz, H., Becker, C., \& Oesch, F. (1987). Mutagenicity experiments on agroclavines, new natural antineoplastic compounds. Cancer Research, 47(7), 1811-1814.

Glatt, H., Jung, R., \& Oesch, F. (1983). Bacterial mutagenicity investigation of epoxides: Drugs, drug metabolites, steroids and pesticides. Mutation Research, 111(2), 99-118. https:/ / doi.org/10.1016/0027-5107(83)90056-8

Glatt, H., Pertz, H., Kasper, R., \& Eich, E. (1992). Clavine alkaloids and derivatives as mutagens detected in the Ames test. Anti-Cancer Drugs, 3(6), 609-614. https:/ / doi.org/10.1097/00001813-199212000-00008
Goetz, P., Srám, R. J., \& Zudová, Z. (1974). The mutagenic effect of lysergic acid diethylamide. I. Cytogenetic analysis. Mutation Research, 26(6), 513516. https:// doi.org/10.1016/s0027-5107(74)80052-7

Golli-Bennour, E.E., Kouidhi, B., Bouslimi, A., Abid-Essefi, S., Hassen, W., \& Bacha, H. (2010). Cytotoxicity and genotoxicity induced by aflatoxin B1, ochratoxin A, and their combination in cultured Vero cells. Journal of Biochemical and Molecular Toxicology, 24(1), 42-50. https://doi.org/10.1002/ibt.20310

González-Arias, C.A., Benitez-Trinidad, A.B., Sordo, M., Robledo-Marenco, L., Medina-Díaz, I.M., Barrón-Vivanco, B.S., ... Rojas-García, A.E. (2014). Low doses of ochratoxin A induce micronucleus formation and delay DNA repair in human lymphocytes. Food and Chemical Toxicology, 74, 249-254. https:// doi.org/10.1016/i.fct.2014.10.006

González-Peñas, E., Vettorazzi, A., Lizarraga, E., Azqueta, A., \& López de Cerain, A. (2019). Report of the IVth Workshop of the Spanish National Network on Mycotoxins and Toxigenic Fungi and Their Decontamination Processes (MICOFOOD), Held in Pamplona, Spain, 29-31 May 2019. Toxins, 11(7), 415. https://doi.org/10.3390/toxins11070415

Graf, U., Würgler, F.E., Katz, A.J., Frei, H., Juon, H., Hall, C.B., \& Kale, P.G. (1984). Somatic mutation and recombination test in Drosophila melanogaster. Environmental Mutagenesis, 6(2), 153-188. https://doi.org/10.1002/em.2860060206

Gupta, R.S., \& Singh, B. (1982). Mutagenic responses of five independent genetic loci in $\mathrm{CHO}$ cells to a variety of mutagens. Development and characteristics of a mutagen screening system based on selection for multiple drug-resistant markers. Mutation Research, 94(2), 449-466. https:// doi.org/10.1016/0027-5107(82)90307-4

Gürbüzel, M., Uysal, H., \& Kız1let, H. (2015). Assessment of genotoxic potential of two mycotoxins in the wing spot test of Drosophila melanogaster. Toxicology and Industrial Health, 31(3), 261-267. https:// doi.org/10.1177/0748233712472528

Hagmar, L., Brøgger, A., Hansteen, I.L., Heim, S., Högstedt, B., Knudsen, L., ... Nordenson, I. (1994). Cancer risk in humans predicted by increased levels of chromosomal aberrations in lymphocytes: Nordic study group on the health risk of chromosome damage. Cancer Research, 54(11), 2919-2922.

Hansen, T.J. (1984). Ames mutagenicity tests on purified 3-nitropropionic acid. Food and Chemical Toxicology, 22(5), 399-401. https:// doi.org/10.1016/0278-6915(84)90370-3

Hashimoto, K., Nakajima, Y., Matsumura, S., \& Chatani, F. (2010). An in vitro micronucleus assay with size-classified micronucleus counting to discriminate aneugens from clastogens. Toxicology in vitro: An International Journal Published in Association with BIBRA, 24(1), 208-216. https://doi.org/10.1016/i.tiv.2009.09.006

Hassanane, M., Abdalla, E., El-Fiky, S., Amer, M., \& Hamdy, A. (2000). Mutagenicity of the mycotoxin diacetoxyscirpenol on somatic and germ cells of mice. Mycotoxin Research, 16(1), 53-64. https://doi.org/10.1007/BF02946105

Hassen, W., Ayed-Boussema, I., Oscoz, A.A., Lopez, A.D.C., \& Bacha, H. (2007). The role of oxidative stress in zearalenone-mediated toxicity in Hep G2 cells: Oxidative DNA damage, gluthatione depletion and stress $\begin{array}{lll}\text { proteins induction. Toxicology, 232(3), 294-302. } & \end{array}$ https://doi.org/10.1016/j.tox.2007.01.015

Heddle, J.A., Cimino, M.C., Hayashi, M., Romagna, F., Shelby, M.D., Tucker, J.D., ... MacGregor, J.T. (1991). Micronuclei as an index of cytogenetic damage: Past, present, and future. Environmental and Molecular Mutagenesis, $18(4), \quad 277-291$. https://doi.org/10.1002/em.2850180414

Helleday, T. (2003). Pathways for mitotic homologous recombination in mammalian cells. Mutation Research, 532(1-2), 103-115. https:// doi.org/10.1016/j.mrfmmm.2003.08.013

Hennig, A., Fink-Gremmels, J., \& Leistner, L. (1991). Mutagenicity and effects of ochratoxin A on the frequency of sister chromatid exchange after metabolic activation. IARC Scientific Publications, 115, 255-260.

Henninger, C., Huelsenbeck, J., Huelsenbeck, S., Grösch, S., Schad, A., Lackner, K.J., ... Fritz, G. (2012). The lipid lowering drug lovastatin protects against doxorubicin-induced hepatotoxicity. Toxicology and $\begin{array}{lll}\text { Applied } & \text { Pharmacology, 261(1), 66-73. }\end{array}$ https://doi.org/10.1016/i.taap.2012.03.012

Higa, Y., Kawabe, M., Nabae, K., Toda, Y., Kitamoto, S., Hara, T., ... Takahashi, M. (2007). Kojic acid -absence of tumor-initiating activity in rat liver, and of carcinogenic and photo-genotoxic potential in mouse skin. The Journal of Toxicological Sciences, 32(2), 143-159. https://doi.org/10.2131/jts.32.143

Horvatovich, K., Hafner, D., Bodnár, Z., Berta, G., Hancz, C., Dutton, M., \& Kovács, M. (2013). Dose-related genotoxic effect of T-2 toxin measured by comet assay using peripheral blood mononuclear cells of healthy pigs. Acta Veterinaria Hungarica, 61(2), 175-186. https:// doi.org/10.1556/AVet.2013.010 
Hradil, C.M., Hallock, Y.F., Clardy, J., Kenfield, D.S., \& Strobel, G. (1989). Phytotoxins from Alternaria cassiae. Phytochemistry, 28(1), 73-75. https://doi.org/10.1016/0031-9422(89)85011-3

Hsia, C.C., Wu, J.L., Lu, X.Q., \& Li, Y.S. (1988). Natural occurrence and clastogenic effects of nivalenol, deoxynivalenol, 3-acetyldeoxynivalenol, 15-acetyl-deoxynivalenol, and zearalenone in corn from a high-risk area of esophageal cancer. Cancer Detection and Prevention, 13(2), 79-86.

Hussein, H.S., \& Brasel, J.M. (2001). Toxicity, metabolism, and impact of mycotoxins on humans and animals. Toxicology, 167(2), 101-134. https:// doi.org/10.1016/s0300-483x(01)00471-1

Inoue, H., Baba, H., Awano, K., \& Yoshikawa, K. (1995). Genotoxic effect of griseofulvin in somatic cells of Drosophila melanogaster. Mutation Research, 343(4), 229-234. https:// doi.org/10.1016/0165-1218(95)90018-

Ivandić, E., \& Bašić-Jukić, N. (2014). Liver damage caused by atorvastatin and cyclosporine in patients with renal transplant. Acta Medica Croatica: Casopis Hravatske Akademije Medicinskih Znanosti, 68(2), 175-178.

Jafari, M., Rezaei, M., Kalantari, H., \& Hashemitabar, M. (2013). Determination of cell death induced by lovastatin on human colon cell line ht29 using the comet assay. Jundishapur Journal of Natural Pharmaceutical Products, 8(4), 187-191.

Jakšić, D., Puel, O., Canlet, C., Kopjar, N., Kosalec, I., \& Klarić, M.Š. (2012). Cytotoxicity and genotoxicity of versicolorins and 5methoxysterigmatocystin in A549 cells. Archives of Toxicology, 86(10), 1583-1591. https:// doi.org/10.1007/s00204-012-0871-x

Jeswal, P. (1996). Citrinin-induced chromosomal abnormalities in the bone marrow cells of Mus musculus. Cytobios, 86(344), 29-33.

Kamp, H.G., Eisenbrand, G., Janzowski, C., Kiossev, J., Latendresse, J.R., Schlatter, J., \& Turesky, R.J. (2005). Ochratoxin A induces oxidative DNA damage in liver and kidney after oral dosing to rats. Molecular Nutrition \& Food Research, 49(12), 1160-1167. https://doi.org/10.1002/mnfr.200500124

Karuna, R., \& Rao, B.S. (2013). Lack of micronuclei induction by fumonisin B1 mycotoxin in BALB/c mice. Mycotoxin Research, 29(1), 9-15. https:// doi.org/10.1007/s12550-012-0149-4

Kawai, K., Mori, H., \& Kitamura, J. (1983). The uncoupling effect of flavoglaucin, a quinol pigment from Aspergillus chevalieri (Mangin), on mitochondrial respiration. Toxicology Letters, 19(3), 321-325. https://doi.org/10.1016/0378-4274(83)90137-6

Kawai, K., Shiojiri, H., Nakamaru, T., Nozawa, Y., Sugie, S., Mori, H., Ogihara, Y. (1985). Cytotoxicity and genotoxicity of xenoclauxin and desacetyl duclauxin from Penicillium duclauxii (delacroix). Cell Biology and Toxicology, 1(2), 1-10. https://doi.org/10.1007/BF00717786

Kaynarca, H. doruk, Hecer, C., \& Ulusoy, B. (2019). Mycotoxin hazard in meat and meat products. Atatürk Üniversitesi Veteriner Bilimleri Dergisi, 14(1), 90-97. https:// doi.org/10.17094/ataunivbd.449705

Kirsch-Volders, M., Elhajouji, A., Cundari, E., \& Van Hummelen, P. (1997). The in vitro micronucleus test: A multi-endpoint assay to detect simultaneously mitotic delay, apoptosis, chromosome breakage, chromosome loss and non-disjunction. Mutation Research, 392(1-2), 1930. https://doi.org/10.1016/s0165-1218(97)00042-6

Klarić, M.S., Darabos, D., Rozgaj, R., Kasuba, V., \& Pepeljnjak, S. (2010). Beauvericin and ochratoxin A genotoxicity evaluated using the alkaline comet assay: Single and combined genotoxic action. Archives of Toxicology, 84(8), 641-650. https://doi.org/10.1007/s00204-010-0535-7

Klarić, M.S., Zelježić, D., Rumora, L., Peraica, M., Pepeljnjak, S., \& Domijan, A.M. (2012). A potential role of calcium in apoptosis and aberrant chromatin forms in porcine kidney PK15 cells induced by individual and combined ochratoxin A and citrinin. Archives of Toxicology, 86(1), 97-107. https:// doi.org/10.1007/s00204-011-0735-9

Knasmüller, S., Bresgen, N., Kassie, F., Mersch-Sundermann, V., Gelderblom, W., Zöhrer, E., \& Eckl, P.M. (1997). Genotoxic effects of three Fusarium mycotoxins, fumonisin B1, moniliformin and vomitoxin in bacteria and in primary cultures of rat hepatocytes. Mutation Research, 391(1-2), 39-48. https://doi.org/10.1016/s0165-1218(97)00030-x

Kocan, R.M., Landolt, M.L., \& Sabo, K.M. (1982). Anaphase aberrations: A measure of genotoxicity in mutagen-treated fish cells. Environmental Mutagenesis, 4(2), 181-189. https:/ / doi.org/10.1002/em.2860040208

Kokkonen, M., Ojala, L., Parikka, P., \& Jestoi, M. (2010). Mycotoxin production of selected Fusarium species at different culture conditions. International Journal of Food Microbiology, 143(1-2), 17-25. https:// doi.org/10.1016/i.ijfoodmicro.2010.07.015

Koppen, G., \& Verschaeve, L. (1996). The alkaline comet test on plant cells: A new genotoxicity test for DNA strand breaks in Vicia faba root cells. Mutation Research, 360(3), 193-200. https://doi.org/10.1016/s01651161(96)90017-5

Krishna, G., Kropko, M.L., \& Theiss, J.C. (1989). Use of the cytokinesis-block method for the analysis of micronuclei in V79 Chinese hamster lung cells: Results with mitomycin C and cyclophosphamide. Mutation Research, 222(1), 63-69. https:// doi.org/10.1016/0165-1218(89)90036-0

Krivobok, S., Olivier, P., Marzin, D.R., Seigle-Murandi, F., \& Steiman, R (1987). Study of the genotoxic potential of 17 mycotoxins with the SOS

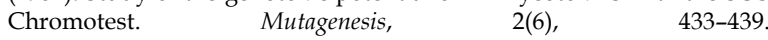
https://doi.org/10.1093/mutage/2.6.433

Krivobok, S., Seigle-Murandi, F., Steiman, R., Marzin, D.R., \& Betina, V. (1992). Mutagenicity of substituted anthraquinones in the Ames/Salmonella microsome system. Mutation Research, 279(1), 1-8. https:// doi.org/10.1016/0165-1218(92)90259-3

Kuhr, I., Fuska, J., Sedmera, P., Podojil, M., Vokoun, J., \& Vanĕk, Z. (1973). An antitumor antibiotic produced by Penicillium stipitatum Thom; its identity with duclauxin. The Journal of Antibiotics, 26(9), 535-536. https://doi.org/10.7164/antibiotics.26.535

Kuroda, K., Hibi, D., Ishii, Y., Takasu, S., Kijima, A., Matsushita, K., ... Umemura, T. (2014). Ochratoxin A induces DNA double-strand breaks and large deletion mutations in the carcinogenic target site of gpt delta rats. Mutagenesis, 29(1), 27-36. https://doi.org/10.1093/mutage/get054

Kuroda, K., Ishii, Y., Takasu, S., Kijima, A., Matsushita, K., Watanabe, M., ... Umemura, T. (2013). Cell cycle progression, but not genotoxic activity, mainly contributes to citrinin-induced renal carcinogenesis. Toxicology, 311(3), 216-224. https:/ / doi.org/10.1016/j.tox.2013.07.003

Le Hegarat, L., Dumont, J., Josse, R., Huet, S., Lanceleur, R., Mourot, A., .. Fessard, V. (2010). Assessment of the genotoxic potential of indirect chemical mutagens in HepaRG cells by the comet and the cytokinesisblock micronucleus assays. Mutagenesis, 25(6), 555-560. https://doi.org/10.1093/mutage/geq039

Lebrun, S., \& Föllmann, W. (2002). Detection of ochratoxin A-induced DNA damage in MDCK cells by alkaline single cell gel electrophoresis (comet $\begin{array}{llll}\text { assay). Archives of Toxicology, 75(11), 734-741. } & \end{array}$ https:// doi.org/10.1007/s00204-001-0291-9

Lebrun, S., Golka, K., Schulze, H., \& Föllmann, W. (2006). Glutathione Stransferase polymorphisms and ochratoxin A toxicity in primary human urothelial cells. Toxicology, 224(1-2), 81-90. https:// doi.org/10.1016/j.tox.2006.04.034

Lee, H.Z, Lin, C.J., Yang, W.H., Leung, W.C., \& Chang, S.P. (2006). Aloeemodin induced DNA damage through generation of reactive oxygen species in human lung carcinoma cells. Cancer Letters, 239(1), 55-63. https:// doi.org/10.1016/i.canlet.2005.07.036

Lerda, D., Biaggi Bistoni, M., Peralta, N., Ychari, S., Vazquez, M., \& Bosio, G. (2005). Fumonisins in foods from Cordoba (Argentina), presence and genotoxicity. Food and Chemical Toxicology, 43(5), 691-698. https://doi.org/10.1016/j.fct.2004.12.019

Lerda, D., Biagi Bistoni, M., Pelliccioni, P., \& Litterio, N. (2010). Allium cepa as a biomonitor of ochratoxin A toxicity and genotoxicity. Plant Biology (Stuttgart, Germany), 12(4), 685-688. https://doi.org/10.1111/i.14388677.2010.00337.x

Li, J.H., \& Lin, L.F. (1998). Genetic toxicology of abused drugs: A brief review. Mutagenesis, 13(6), 557-565. https://doi.org/10.1093/mutage/13.6.557

Li, M.X. (1988). Mutagenicity and carcinogenicity of T-2 toxin, trichothecene produced by Fusarium fungi. Zhonghua Zhong Liu Za Zhi [Chinese Journal of Oncology], 10(5), 326-329.

Li, W.Y., Chan, R.Y.K., Yu, P.H.F., \& Chan, S.W. (2013). Emodin induces cytotoxic effect in human breast carcinoma MCF-7 cell through modulating the expression of apoptosis-related genes. Pharmaceutical Biology, 51(9), https:// doi.org/10.3109/13880209.2013.782322 $1175-1181$.

Li, Y., Luan, Y., Qi, X., Li, M., Gong, L., Xue, X., ... Ren, J. (2010). Emodin triggers DNA double-strand breaks by stabilizing topoisomerase IIDNA cleavage complexes and by inhibiting ATP hydrolysis of topoisomerase II. Toxicological Sciences: An Official Journal of the Society of Toxicology, 118(2), 435-443. https:// doi.org/10.1093/toxsci/kfq282

Liberman, D.F., Schaefer, F.L., Fink, R.C., Ramgopal, M., Ghosh, A.C., \& Mulcahy, R. (1980). Mutagenicity of islandicin and chrysophanol in the Salmonella/microsome system. Applied and Environmental Microbiology, 40(3), 476-479.

Limón, M.C., Rodríguez-Ortiz, R., \& Avalos, J. (2010). Bikaverin production and applications. Applied Microbiology and Biotechnology, 87(1), 21-29. https://doi.org/10.1007/s00253-010-2551-1

Lin, L., Zhang, J., Wang, P., Wang, Y., \& Chen, J. (1998). Thin-layer chromatography of mycotoxins and comparison with other chromatographic methods. Journal of Chromatography A, 815(1), 3-20. https://doi.org/10.1016/S0021-9673(98)00204-0

Lindholm, C., Norppa, H., Hayashi, M., \& Sorsa, M. (1991). Induction of micronuclei and anaphase aberrations by cytochalasin B in human lymphocyte cultures. Mutation Research, 260(4), 369-375. https:// doi.org/10.1016/0165-1218(91)90022-e 
Lioi, M.B., Santoro, A., Barbieri, R., Salzano, S., \& Ursini, M.V. (2004). Ochratoxin A and zearalenone: A comparative study on genotoxic effects and cell death induced in bovine lymphocytes. Mutation Research, 557(1), 19-27. https://doi.org/10.1016/i.mrgentox.2003.09.009

Liu, B.H., Yu, F.Y., Wu, T.S., Li, S.Y., Su, M.C., Wang, M.C., \& Shih, S.M. (2003). Evaluation of genotoxic risk and oxidative DNA damage in mammalian cells exposed to mycotoxins, patulin and citrinin. Toxicology and Applied Pharmacology, 191(3), 255-263. https:// doi.org/10.1016/s0041-008x(03)00254-0

Liu, J., Wang, Y., Cui, J., Xing, L., Shen, H., Wu, S., ... Zhang, X. (2012). Ochratoxin A induces oxidative DNA damage and G1 phase arrest in human peripheral blood mononuclear cells in vitro. Toxicology Letters, 211(2), 164-171. https:// doi.org/10.1016/i.toxlet.2012.03.800

Liu, W., Xi, J., Cao, Y., You, X., Chen, R., Zhang, X., ... Luan, Y. (2019). An adaption of human-induced hepatocytes to in vitro genetic toxicity $\begin{array}{llll}\text { Tests. } & \text { Mutagenesis, } & \text { 34(2), }\end{array}$ https://doi.org/10.1093/mutage/gey041

Loi, M., Fanelli, F., Liuzzi, V.C., Logrieco, A.F., \& Mulè, G. (2017). Mycotoxin Biotransformation by Native and Commercial Enzymes: Present and Future Perspectives. Toxins, 9(4). https:// doi.org/10.3390/toxins9040111

Lu, H.F., Lai, T.Y., Hsia, T.C., Tang, Y.J., Yang, J.S., Chiang, J.H., ... Chung, J.G. (2010). Danthron induces DNA damage and inhibits DNA repair gene expressions in GBM 8401 human brain glioblastoma multiforms cells. Neurochemical Research, 35(7), 1105-1110. https:// doi.org/10.1007/s11064-010-0161-z

Lusky, K., Wagner, U., Stähr, B., Doberschütz, K.D., \& Peter, W. (1991). Investigations on possible genotoxic effects ofFusarium toxins in boars. Mycotoxin Research, 7(1), 29-34. https:/ / doi.org/10.1007/BF03192161

Madle, E., Korte, A., \& Beek, B. (1986). Species differences in mutagenicity testing: I. Micronucleus and SCE tests in rats, mice, and Chinese hamsters with aflatoxin B1. Teratogenesis, Carcinogenesis, and Mutagenesis, 6(1), 1-13. https:// doi.org/10.1002/tcm.1770060102

Mailhes, J.B., Marchetti, F., \& Aardema, M.J. (1993). Griseofulvin-induced aneuploidy and meiotic delay in mouse oocytes: Effect of dose and harvest time. Mutation Research, 300(3-4), 155-163. https://doi.org/10.1016/0165-1218(93)90047-h

Malaveille, C., Brun, G., \& Bartsch, H. (1991). Genotoxicity of ochratoxin A and structurally related compounds in Escherichia coli strains: Studies on their mode of action. IARC Scientific Publications, 115, 261-266.

Malaveille, C., Brun, G., \& Bartsch, H. (1994). Structure-activity studies in E. coli strains on ochratoxin A (OTA) and its analogues implicate a genotoxic free radical and a cytotoxic thiol derivative as reactive metabolites. Mutation Research, 307(1), 141-147. https://doi.org/10.1016/0027-5107(94)90286-0

Mally, A., Pepe, G., Ravoori, S., Fiore, M., Gupta, R.C., Dekant, W., \& Mosesso, P. (2005). Ochratoxin a causes DNA damage and cytogenetic effects but no DNA adducts in rats. Chemical Research in Toxicology, 18(8), 1253-1261. https://doi.org/10.1021/tx049650x

Mamur, S., Ünal, F., Yılmaz, S., Erikel, E., \& Yüzbaşığlu, D. (2018a). Evaluation of the cytotoxic and genotoxic effects of mycotoxin fusaric acid. Drug and Chemical Toxicology, 11, 1-9. https:// doi.org/10.1080/01480545.2018.1499772

Mamur, S., Yuzbasioglu, D., Yilmaz, S., Erikel, E., \& Unal, F. (2018b). Assessment of cytotoxic and genotoxic effects of enniatin-A in vitro. Food Additives $\mathcal{E}$ Contaminants. Part A, Chemistry, Analysis, Control, Exposure \& Risk Assessment, 35(8), 1633-1644. https://doi.org/10.1080/19440049.2018.1486513

Marchetti, F., Aardema, M., Beevers, C., van Benthem, J., Douglas, G.R., Godschalk, R., ... Williams, A. (2018). Simulation of mouse and rat spermatogenesis to inform genotoxicity testing using OECD test guideline 488. Mutation Research, 832-833, 19-28. https://doi.org/10.1016/i.mrgentox.2018.05.020

Marillia, E.F., \& Scoles, G.J. (1996). The use of RAPD markers in Hordeum phylogeny. Genome, 39(4), 646-654. https:// doi.org/10.1139/g96-082

Maron, D.M., \& Ames, B.N. (1983). Revised methods for the Salmonella mutagenicity test. Mutation Research, 113(3-4), 173-215. https:// doi.org/10.1016/0165-1161(83)90010-9

Matter, B.E., Donatsch, P., Racine, R.R., Schmid, B., \& Suter, W. (1982). Genotoxicity evaluation of cyclosporin A, a new immunosuppressive agent. Mutation Research, 105(4), 257-264. https:/ / doi.org/10.1016/0165-7992(82)90039-2

Matthiaschk, G., \& Korte, A. (1986). Studies on the embryotoxicity and mutagenicity of mycotoxins. Mycotoxin Research, 2(2), 89-97. https://doi.org/10.1007/BF03191969

McGregor, D.B., Brown, A., Cattanach, P., Edwards, I., McBride, D., Riach, C., \& Caspary, W.J. (1988). Responses of the L5178Y tk+/tk- mouse lymphoma cell forward mutation assay: III. 72 coded chemicals.
Environmental and Molecular Mutagenesis, 12(1), 85-154. https://doi.org/10.1002/em.2860120111

Mengs, U., Schuler, D., \& Marshall, R.R. (2001). No induction of chromosomal aberrations in Chinese hamster ovary cells by chrysophanol. Mutation Research, 492(1-2), 69-72. https://doi.org/10.1016/s1383-5718(01)00150-4

Migliore, L., \& Nieri, M. (1991). Evaluation of twelve potential aneuploidogenic chemicals by the in vitro human lymphocyte micronucleus assay. Toxicology in Vitro: An International Journal Published in Association with BIBRA, 5(4), 325-336. https://doi.org/10.1016/0887-2333(91)90009-3

Mikami, Y., Fukushima, K., Arai, T., Abe, F., Shibuya, H., \& Ommura, Y. (1984). Leucinostatins, peptide mycotoxins produced by Paecilomyces lilacinus and their possible roles in fungal infection. Zentralblatt Fur Bakteriologie, Mikrobiologie, Und Hygiene. Series A, Medical Microbiology, Infectious Diseases, Virology, Parasitology, 257(2), 275-283.

Miranda, D.D.C., Arçari, D.P., Ladeira, M.S.P., Calori-Domingues, M.A., Romero, A. C., Salvadori, D. M. F., ... Ribeiro, M. L. (2007). Analysis of DNA damage induced by aflatoxin B1 in Dunkin-Hartley guinea pigs. Mycopathologia, 163(5), 275-280. https://doi.org/10.1007/s11046-0079014-y

Mirsalis, J.C., Tyson, C.K., \& Butterworth, B.E. (1982). Detection of genotoxic carcinogens in the in vivo-in vitro hepatocyte DNA repair assay. Environmental Mutagenesis, 4(5), 553-562. https://doi.org/10.1002/em.2860040506

Miyamae, Y., Iwasaki, K., Kinae, N., Tsuda, S., Murakami, M., Tanaka, M., \& Sasaki, Y.F. (1997). Detection of DNA lesions induced by chemical mutagens using the single-cell gel electrophoresis (comet) assay. 2 Relationship between DNA migration and alkaline condition. Mutation Research, 393(1-2), 107-113. https://doi.org/10.1016/s1383$\underline{5718(97) 00091-0}$

Mok, Z.R., \& Tey, H.L. (2018). Acquired idiopathic generalized anhidriosis: Successful treatment with cyclosporine in two cases. Dermatologic Therapy, 31(2), e12579. https:/ / doi.org/10.1111/dth.12579

Mori, H., Kawai, K., Ohbayashi, F., Kitamura, J., \& Nozawa, Y. (1983). Genotoxicity of quinone pigments from pathogenic fungi. Mutation Research, 122(1), 29-34. https:/ / doi.org/10.1016/0165-7992(83)90138-0

Mori, H., Kawai, K., Ohbayashi, F., Kuniyasu, T., Yamazaki, M., Hamasaki, T., \& Williams, G.M. (1984). Genotoxicity of a variety of mycotoxins in the hepatocyte primary culture/DNA repair test using rat and mouse hepatocytes. Cancer Research, 44(7), 2918-2923.

Mori, H., Sugie, S., Yoshimi, N., Kitamura, J., Niwa, M., Hamasaki, T., \& Kawai, K. (1986). Genotoxic effects of a variety of sterigmatocystinrelated compounds in the hepatocyte/DNA-repair test and the Salmonella microsome assay. Mutation Research, 173(3), 217-222. https://doi.org/10.1016/0165-7992(86)90039-4

Mori, H., Yoshimi, N., Iwata, H., Tanaka, T., Kawai, K., \& Sankawa, U. (1988). Additional survey on genotoxicity of natural anthraquinones in the hepatocyte primary culture/DNA repair assay. The Journal of Toxicological Sciences, 13(3), 161-166. https:/ / doi.org/10.2131/jts.13.161

Mori, Hideki, Kitamura, J., Sugie, S., Kawai, K., \& Hamasaki, T. (1985). Genotoxicity of fungal metabolites related to aflatoxin B1 biosynthesis. Mutation Research Letters, 143(3), 121-125. https://doi.org/10.1016/S0165-7992(85)80021-X

Moulé, Y., Hermann, M., \& Renault, G. (1981). Negative response of PR toxin in the Salmonella typhimurium/microsome test and sisterchromatid exchange assay. Mutation Research, 89(3), 203-207. https://doi.org/10.1016/0165-1218(81)90238-x

Muehlbauer, P.A., \& Schuler, M.J. (2005). Detection of numerical chromosomal aberrations by flow cytometry: A novel process for identifying aneugenic agents. Mutation Research, 585(1), 156-169. https://doi.org/10.1016/j.mrgentox.2005.05.002

Mueller, S.O., Schmitt, M., Dekant, W., Stopper, H., Schlatter, J., Schreier, P., \& Lutz, W.K. (1999). Occurrence of emodin, chrysophanol and physcion in vegetables, herbs and liquors. Genotoxicity and antigenotoxicity of the anthraquinones and of the whole plants. Food and Chemical Toxicology, 37(5), 481-491. https://doi.org/10.1016/s02786915(99)00027-7

Munday, R., Pearson, A., \& Ferguson, L.R. (1993). Mouse micronucleus assays of sporidesmin, the toxin associated with facial eczema in ruminants. Mutation Research, 302(1), 71-74. https://doi.org/10.1016/0165-7992(93)90092-a

Muneer, R.S. (1978). Effects of LSD on human chromosomes. Mutation Research, 51(3), 403-410. https://doi.org/10.1016/0027-5107(78)90128-8

Muthulakshmi, S., Maharajan, K., Habibi, H.R., Kadirvelu, K., \& Venkataramana, M. (2018). Zearalenone induced embryo and neurotoxicity in zebrafish model (Danio rerio): Role of oxidative stress revealed by a multi biomarker study. Chemosphere, 198, 111-121. https://doi.org/10.1016/j.chemosphere.2018.01.141 
Müller, S.O., Eckert, I., Lutz, W.K., \& Stopper, H. (1996). Genotoxicity of the laxative drug components emodin, aloe-emodin and danthron in mammalian cells: Topoisomerase II mediated? Mutation Research, 371(3-4), 165-173. https:/ / doi.org/10.1016/s0165-1218(96)90105-6

Müller, T. (1987). Carcinogenic and genotoxic effects of mycotoxins. Die Nahrung, 31(2), 117-125. https:// doi.org/10.1002/food.19870310205

Nesslany, F., Simar-Meintières, S., Ficheux, H., \& Marzin, D. (2009). Aloeemodin-induced DNA fragmentation in the mouse in vivo comet assay. Mutation Research, 678(1), 13-19. https://doi.org/10.1016/j.mrgentox.2009.06.004

Nestmann, E.R., Nasim, A., Haynes, R.H., \& Kowbel, D.J. (1981). Genetic activity of actinomycin D in Saccharomyces cerevisiae but not in Escherichia coli. Mutation Research, 89(3), 229-236.

Ni, C.H., Yu, C.S., Lu, H.F., Yang, J.S., Huang, H.Y., Chen, P.Y., ... Chung, J.G. (2014). Chrysophanol-induced cell death (necrosis) in human lung cancer A549 cells is mediated through increasing reactive oxygen species and decreasing the level of mitochondrial membrane potential. $\begin{array}{lll}\text { Environmental Toxicology, } & \text { 29(7), }\end{array}$ https:// doi.org/10.1002/tox.21801

Nielsen, J., Friedrich, U., Jacobsen, E., \& Tsuboi, T. (1968). Lysergide and chromosome abnormalities. British Medical Journal, 2(5608), 801-803.

Nieminen, S.M., Mäki-Paakkanen, J., Hirvonen, M.R., Roponen, M., \& von Wright, A. (2002). Genotoxicity of gliotoxin, a secondary metabolite of Aspergillus fumigatus, in a battery of short-term test systems. Mutation Research, 520(1-2), 161-170. https://doi.org/10.1016/s13835718(02)00202-4

Nito, S., Ariyuki, F., \& Okaniwa, A. (1988). Spontaneous expulsion of micronuclei by enucleation in the micronucleus assay. Mutation Research, 207(3-4), 185-192. https://doi.org/10.1016/01657992(88)90085-1

Noel, S., \& Rath, S.K. (2006). Randomly amplified polymorphic DNA as a tool for genotoxicity: An assessment. Toxicology and Industrial Health, 22(6), 267-275. https://doi.org/10.1191/0748233706th267oa

Nohynek, G.J., Kirkland, D., Marzin, D., Toutain, H., Leclerc-Ribaud, C., \& Jinnai, H. (2004). An assessment of the genotoxicity and human health risk of topical use of kojic acid [5-hydroxy-2-(hydroxymethyl)- $4 \mathrm{H}$ pyran-4-one]. Food and Chemical Toxicology, 42(1), 93-105. https://doi.org/10.1016/j.fct.2003.08.008

Norberto, A.H., Saúl, F.M., Belén, B., García-Bores Ana, M., Ernesto, M., Guillermo, Á.A., \& Elizabeth, H.E. (2017). Raw data of the effects of Chlorogenic acid in 3-Nitropropionic acid induced toxicity and genotoxicity. Data in Brief, 14, 123-131. https://doi.org/10.1016/j.dib.2017.07.004

Norppa, H., \& Falck, G.C.M. (2003). What do human micronuclei contain? Mutagenesis, 18(3), 221-233. https:// doi.org/10.1093/mutage/18.3.221

Norppa, H., Bonassi, S., Hansteen, I.L., Hagmar, L., Strömberg, U., Rössner, P., ... Fucic, A. (2006). Chromosomal aberrations and SCEs as biomarkers of cancer risk. Mutation Research, 600(1-2), 37-45. https://doi.org/10.1016/j.mrfmmm.2006.05.030

Norred, W.P., Plattner, R.D., Vesonder, R.F., Bacon, C.W., \& Voss, K.A. (1992). Effects of selected secondary metabolites of Fusarium moniliforme on unscheduled synthesis of DNA by rat primary hepatocytes. Food and Chemical Toxicology, 30(3), 233-237. https://doi.org/10.1016/02786915(92)90038-m

Nusuetrong, P., Saito, M., Kikuchi, H., Oshima, Y., Moriya, T., \& Nakahata, N. (2012). Apoptotic effects of satratoxin H is mediated through DNA double-stranded break in PC12 cells. The Journal of Toxicological Sciences, 37(4), 803-812. https:// doi.org/10.2131/jts.37.803

Obrecht-Pflumio, S., Chassat, T., Dirheimer, G., \& Marzin, D. (1999). Genotoxicity of ochratoxin A by Salmonella mutagenicity test after bioactivation by mouse kidney microsomes. Mutation Research, 446(1), 95-102. https:// doi.org/10.1016/s1383-5718(99)00152-7

OECD. (1986). Guideline for Testing of Chemicals "Genetic Toxicology: In vitro Sister Chromatid Exchange Assay in Mammalian Cells" Test No: 479.

OECD. (1997a). Guideline for Testing of Chemicals "In vitro Mammalian Chromosome Aberration Test" Test No: 473.

OECD. (1997b). Guideline for Testing of Chemicals "Mammalian Bone Marrow Chromosome Aberration Test" Test No: 475.

OECD. (2013). Mammalian erythrocyte micronucleus test. In: Guideline for the testing of chemicals. https://www.oecdilibrary.org/environment/test-no-474-mammalian-erythrocytemicronucleus-test 9789264264762-en Accessed: 11 May 2018.

Ogiwara, Y., Sugiura, M., Watanabe, K., Tawara, J., Endo, E., Maruyama, H., ... Kawasako, K. (2015). Evaluation of the repeated-dose liver, bone marrow and peripheral blood micronucleus and comet assays using kojic acid. Mutation Research, 780-781, 111-116. https:/ / doi.org/10.1016/j.mrgentox.2015.01.004
Olive, P.L., \& Banáth, J.P. (1997). Multicell Spheroid Response to Drugs Predicted with the Comet Assay. Cancer Research, 57(24), 5528-5533.

Oliveira, N.G., Castro, M., Rodrigues, A.S., Gil, O.M., Toscano-Rico, J.M., \& Rueff, J. (2002). DNA-PK inhibitor wortmannin enhances DNA damage induced by bleomycin in V79 Chinese hamster cells. Teratogenesis, Carcinogenesis, and Mutagenesis, 22(5), 343-351. https://doi.org/10.1002/tcm.10029

Oliver, J., Meunier, J.R., Awogi, T., Elhajouji, A., Ouldelhkim, M.C., Bichet, N., ... Lorge, E. (2006). SFTG international collaborative study on in vitro micronucleus test V. Using L5178Y cells. Mutation Research, 607(1), 125-152. https://doi.org/10.1016/j.mrgentox.2006.04.004

Oshiro, Y., Piper, C.E., Balwierz, P.S., \& Soelter, S.G. (1991). Chinese hamster ovary cell assays for mutation and chromosome damage: Data from non-carcinogens. Journal of Applied Toxicology: JAT, 11(3), 167-177. https:/ / doi.org/10.1002/jat.2550110304

Ostry, V. (2008). Alternaria mycotoxins: An overview of chemical characterization, producers, toxicity, analysis and occurrence in foodstuffs. World Mycotoxin Journal, 1(2), 175-188 https:// doi.org/10.3920/WMJ2008.x013

Ouanes, Z., Abid, S., Ayed, I., Anane, R., Mobio, T., Creppy, E.E., \& Bacha, H. (2003). Induction of micronuclei by Zearalenone in Vero monkey kidney cells and in bone marrow cells of mice: Protective effect of Vitamin E. Mutation Research, 538(1-2), 63-70. https://doi.org/10.1016/s1383-5718(03)00093-7

Parkes, D.J., \& Scott, D. (1982). A quantitative comparison of cytogenetic effects of anti-tumor agents. Cytogenetics and Cell Genetics, 33(1-2), 2734. https://doi.org/10.1159/000131722

Perry, P., \& Evans, H.J. (1975). Cytological detection of mutagencarcinogen exposure by sister chromatid exchange. Nature, 258(5531), 121-125. https://doi.org/10.1038/258121a0

Pfohl-Leszkowicz, A., Chekir-Ghedira, L., \& Bacha, H. (1995). Genotoxicity of zearalenone, an estrogenic mycotoxin: DNA adduct formation in female mouse tissues. Carcinogenesis, 16(10), 2315-2320. https://doi.org/10.1093/carcin/16.10.2315

Phillips, D.H., \& Arlt, V.M. (2009). Genotoxicity: damage to DNA and its consequences. In: Luch A. (eds) Molecular, Clinical and Environmental Toxicology. Experientia Supplementum, Birkhäuser, Basel, Switzerland, vol. 99, pp. 87-110. https://doi.org/10.1007/978-3-76438336-7_4

Prata-Sena, M., Ramos, A.A., Buttachon, S., Castro-Carvalho, B., Marques, P., Dethoup, T., ... Rocha, E. (2016). Cytotoxic activity of secondary metabolites from marine-derived Fungus Neosartorya siamensis in human cancer cells. Phytotherapy Research: PTR, 30(11), 1862-1871. https://doi.org/10.1002/ptr.5696

Pylkkänen, L., Jahnukainen, K., Parvinen, M., \& Santti, R. (1991). Testicular toxicity and mutagenicity of steroidal and non-steroidal estrogens in the male mouse. Mutation Research, 261(3), 181-191. https:/ / doi.org/10.1016/0165-1218(91)90066-u

Quillardet, P., Huisman, O., D'Ari, R., \& Hofnung, M. (1982). SOS chromotest, a direct assay of induction of an SOS function in Escherichin coli K-12 to measure genotoxicity. Proceedings of the National Academy of Sciences of the United States of America, 79(19), 5971-5975. https://doi.org/10.1073/pnas.79.19.5971

Ramesha, A., Venkataramana, M., Nirmaladevi, D., Gupta, V.K., Chandranayaka, S., \& Srinivas, C. (2015). Cytotoxic effects of oosporein isolated from endophytic fungus Cochliobolus kusanoi. Frontiers in Microbiology, 6, 870. https://doi.org/10.3389/fmicb.2015.00870

Reddy, C.S., Reddy, R.V., Chan, P.K., \& Hayes, A.W. (1980). Mutagenicity of secalonic acid D in mice. Journal of Environmental Pathology and Toxicology, 4(5-6), 31-37.

Rencuzogullari, E., \& Aydin, M. (2018). Methodology of Genotoxic and Teratogenic Studies in Rats. Methods in Molecular Biology (Clifton, N.J.) 1797, 555-575. https://doi.org/10.1007/978-1-4939-7883-0_33

Rezar, V., Frankič, T., Narat, M., Levart, A., \& Salobir, J. (2007). DoseDependent Effects of T-2 Toxin on Performance, Lipid Peroxidation, and Genotoxicity in Broiler Chickens. Poultry Science, 86(6), 1155-1160. https://doi.org/10.1093/ps/86.6.1155

Robbiano, L., Baroni, D., Carrozzino, R., Mereto, E., \& Brambilla, G. (2004). DNA damage and micronuclei induced in rat and human kidney cells by six chemicals carcinogenic to the rat kidney. Toxicology, 204(2), 187195. https:// doi.org/10.1016/j.tox.2004.06.057

Rogers, C.G., \& Héroux-Metcalf, C. (1983). Cytotoxicity and absence of mutagenic activity of vomitoxin (4-deoxynivalenol) in a hepatocytemediated mutation assay with V79 Chinese hamster lung cells. Cancer Letters, 20(1), 29-35. https:/ / doi.org/10.1016/0304-3835(83)90183-0

Rosefort, C., Fauth, E., \& Zankl, H. (2004). Micronuclei induced by aneugens and clastogens in mononucleate and binucleate cells using the cytokinesis block assay. Mutagenesis, 19(4), 277-284. https://doi.org/10.1093/mutage/geh028 
Russo, A., La Fauci, L., Acquaviva, R., Campisi, A., Raciti, G., Scifo, C., ... Galvano, F. (2005). Ochratoxin A-induced DNA damage in human fibroblast: Protective effect of cyanidin 3-O-beta-d-glucoside. The Journal of Nutritional Biochemistry, 16(1), 31-37. https://doi.org/10.1016/i.jnutbio.2004.05.005

Sabater-Vilar, M., Nijmeijer, S., \& Fink-Gremmels, J. (2003). Genotoxicity assessment of five tremorgenic mycotoxins (fumitremorgen $\mathrm{B}$, paxilline, penitrem A, verruculogen, and verrucosidin) produced by molds isolated from fermented meats. Journal of Food Protection, 66(11), 21232129. https:// doi.org/10.4315/0362-028x-66.11.2123

Sakai, M., Abe, K., Okumura, H., Kawamura, O., Sugiura, Y., Horie, Y., \& Ueno, Y. (1992). Genotoxicity of fungi evaluated by SOS microplate assay. Natural Toxins, 1(1), 27-34. https://doi.org/10.1002/nt.2620010107

Salamone, M., Heddle, J., Stuart, E., \& Katz, M. (1980). Towards an improved micronucleus test: Studies on 3 model agents, mitomycin C, cyclophosphamide and dimethylbenzanthracene. Mutation Research, 74(5), 347-356. https://doi.org/10.1016/0165-1161(80)90193-4

Sandhu, S.S., \& Acedo, G.N. (1988). Detection of chemically induced aneuploidy by the Vicia faba root tip assay. Toxicology and Industrial Health, 4(2), 257-267. https:// doi.org/10.1177/074823378800400207

Sasaki, Y.F., Nishidate, E., Izumiyama, F., Matsusaka, N., \& Tsuda, S. (1997). Simple detection of chemical mutagens by the alkaline single-cell gel electrophoresis (Comet) assay in multiple mouse organs (liver, lung, spleen, kidney, and bone marrow). Mutation Research, 391(3), 215-231. https://doi.org/10.1016/S1383-5718(97)00073-9

Savage, J.R. (1993). Update on target theory as applied to chromosomal aberrations. Environmental and Molecular Mutagenesis, 22(4), 198-207. https://doi.org/10.1002/em.2850220404

Savva, D. (2000). The Use of Arbitrarily Primed PCR (AP-PCR) Fingerprinting to Detect Exposure to Genotoxic Chemicals. Ecotoxicology, 9(5), 341-353. https:// doi.org/10.1023/A:1026577326366

Saxena, N., Ansari, K.M., Kumar, R., Dhawan, A., Dwivedi, P.D., \& Das, M. (2009). Patulin causes DNA damage leading to cell cycle arrest and apoptosis through modulation of Bax, $\mathrm{p}(53)$ and $\mathrm{p}(21 / \mathrm{WAF} 1)$ proteins in skin of mice. Toxicology and Applied Pharmacology, 234(2), 192-201. https://doi.org/10.1016/j.taap.2008.09.033

Schaeffer, B.K., Curphey, T.J., \& Longnecker, D.S. (1987). Mutagenicity of L-azaserine for V79 cells in a pancreatic acinar cell-mediated mutagenesis assay. Pancreas, 2(5), 518-522. https://doi.org/10.1097/00006676-198709000-00005

Schafhauser, T., Kirchner, N., Kulik, A., Huijbers, M.M.E., Flor, L., Caradec, T., ... van Pée, K.H. (2016). The cyclochlorotine mycotoxin is produced by the nonribosomal peptide synthetase CctN in Talaromyces islandicus (Penicillium islandicum). Environmental Microbiology, 18(11), 3728-3741. https://doi.org/10.1111/1462-2920.13294

Scheutwinkel, M., v. d. Hude, W., \& Basler, A. (1986). Studies on the genotoxicity of the anabolic drugs trenbolone and zeranol. Archives of Toxicology, 59(1), 4-6. https:// doi.org/10.1007/BF00263948

Schoch, U., Lüthy, J., \& Schlatter, C. (1984). Mutagenicity testing of commercially used strains of $P$. camemberti and P. roqueforti. Zeitschrift Fur Lebensmittel-Untersuchung Und -Forschung, 178(5), 351-355. https://doi.org/10.1007/bf01042226

Schrader, T.J., Cherry, W., Soper, K., \& Langlois, I. (2006). Further examination of the effects of nitrosylation on Alternaria alternata mycotoxin mutagenicity in vitro. Mutation Research, 606(1-2), 61-71. https:// doi.org/10.1016/j.mrgentox.2006.02.008

Schrader, T.J., Cherry, W., Soper, K., Langlois, I., \& Vijay, H.M. (2001). Examination of Alternaria alternata mutagenicity and effects of nitrosylation using the Ames Salmonella test. Teratogenesis, Carcinogenesis, and Mutagenesis, 21(4), 261-274. https://doi.org/10.1002/tcm.1014

Schumacher, D.M., Metzler, M., \& Lehmann, L. (2005). Mutagenicity of the mycotoxin patulin in cultured Chinese hamster V79 cells, and its modulation by intracellular glutathione. Archives of Toxicology, 79(2), 110-121. https:// doi.org/10.1007/s00204-004-0612-x

Schwarz, C., Tiessen, C., Kreutzer, M., Stark, T., Hofmann, T., \& Marko, D. (2012). Characterization of a genotoxic impact compound in Alternaria alternata infested rice as Altertoxin II. Archives of Toxicology, 86(12), 1911-1925. https://doi.org/10.1007/s00204-012-0958-4

Scott, P.M., \& Stoltz, D.R. (1980). Mutagens produced by Alternaria alternata. Mutation Research, 78(1), 33-40. https:// doi.org/10.1016/0165-1218(80)90023-3

Šegvić Klarić, M., Jakšić Despot, D., Kopjar, N., Rašić, D., Kocsubé, S., Varga, J., \& Peraica, M. (2015). Cytotoxic and genotoxic potencies of single and combined spore extracts of airborne OTA-producing and OTA-non-producing Aspergilli in Human lung A549 cells. Ecotoxicology and Environmental Safety, 120, 206-214. https://doi.org/10.1016/j.ecoenv.2015.06.002
Shah, A.J., Prasanth Kumar, S., Rao, M.V., \& Pandya, H.A. (2018). Ameliorative effects of curcumin towards cyclosporine-induced genotoxic potential: An in vitro and in silico study. Drug and Chemical Toxicology, 41(3), 259-269. https:/ / doi.org/10.1080/01480545.2017.1380660

Shepherd, J., Tsao, M.S., \& Duguid, W.P. (1990). Genotoxicity of pancreatic chemical carcinogens to propagable cultured normal pancreatic epithelial cells. Experimental and Molecular Pathology, 53(3), 203-210. https:// doi.org/10.1016/0014-4800(90)90044-e

Shibuya, T., Murota, T., Sakamoto, K., Iwahara, S., \& Ikeno, M. (1982). Mutagenicity and dominant lethal test of kojic acid-Ames test, forward mutation test in cultured Chinese hamster cells and dominant lethal test in mice. The Journal of Toxicological Sciences, 7(4), 255-262. https://doi.org/10.2131/its.7.255

Shin, K.T., Guo, J., Niu, Y.J., \& Cui, X.S. (2018). The toxic effect of aflatoxin B1 on early porcine embryonic development. Theriogenology, 118, 157163. https:/ / doi.org/10.1016/j.theriogenology.2018.06.002

Simarro Doorten, Y., Nijmeijer, S., de Nijs-Tjon, L., \& Fink-Gremmels, J. (2006). Metabolism-mediated Ochratoxin A genotoxicity in the singlecell gel electrophoresis (Comet) assay. Food and Chemical Toxicology, 44(2), 261-270. https:// doi.org/10.1016/i.fct.2005.07.009

Singh, S., Banerjee, S., Chattopadhyay, P., Borthakur, S.K., \& Veer, V. (2015) Deoxynivalenol induces cytotoxicity and genotoxicity in animal primary cell culture. Toxicology Mechanisms and Methods, 25(3), 184-191. https://doi.org/10.3109/15376516.2015.1006743

Sokolovic, M., Garaj-Vrhovac, V., Ramic, S., \& Simpraga, B. (2007). Chicken nucleated blood cells as a cellular model for genotoxicity testing using the comet assay. Food and Chemical Toxicology, 45(11), 2165-2170. https://doi.org/10.1016/i.fct.2007.05.013

Solhaug, A., Vines, L.L., Ivanova, L., Spilsberg, B., Holme, J.A., Pestka, J., .. Eriksen, G.S. (2012). Mechanisms involved in alternariol-induced cell cycle arrest. Mutation Research, 738-739, 1-11. https://doi.org/10.1016/j.mrfmmm.2012.09.001

Song, E., Xia, X., Su, C., Dong, W., Xian, Y., Wang, W., \& Song, Y. (2014). Hepatotoxicity and genotoxicity of patulin in mice, and its modulation by green tea polyphenols administration. Food and Chemical Toxicology, 71, 122-127. https:// doi.org/10.1016/i.fct.2014.06.009

Sonoda, E., Sasaki, M.S., Morrison, C., Yamaguchi-Iwai, Y., Takata, M., \& Takeda, S. (1999). Sister chromatid exchanges are mediated by homologous recombination in vertebrate cells. Molecular and Cellular Biology, 19(7), 5166-5169.

Sorenson, W.G., Tucker, J.D., \& Simpson, J.P. (1984). Mutagenicity of tetramic mycotoxin cyclopiazonic acid. Applied and Environmental Microbiology, 47(6), 1355-1357.

Šrám, R.J., Zudová, Z., \& Goetz, P. (1974). The mutagenic effect or lysergic acid diethylamide II. Dominant lethal test in mice. Mutation Research, 26(6), 517-522. https:// doi.org/10.1016/S0027-5107(74)80053-9

Stanimirovic, Z., Stevanovic, J., Bajic, V., \& Radovic, I. (2007). Evaluation of genotoxic effects of fumagillin by cytogenetic tests in vivo. Mutation Research, 628(1), 1-10. https:// doi.org/10.1016/i.mrgentox.2006.09.014

Stark, A.A., Townsend, J.M., Wogan, G.N., Demain, A.L., Manmade, A., \& Ghosh, A.C. (1978). Mutagenicity and antibacterial activity of mycotoxins produced by Penicillium islandicum Sopp and Penicillium rugulosum. Journal of Environmental Pathology and Toxicology, 2(2), 313324

Stevanovic, J., Stanimirovic, Z., Radakovic, M., \& Stojic, V. (2008). In vitro evaluation of the clastogenicity of fumagillin. Environmental and Molecular Mutagenesis, 49(8), 594-601. https://doi.org/10.1002/em.20409

Surrallés, J., Xamena, N., Creus, A., \& Marcos, R. (1995). The suitability of the micronucleus assay in human lymphocytes as a new biomarker of excision repair. Mutation Research, 342(1-2), 43-59. https://doi.org/10.1016/0165-1218(95)90089-6

Suzuki, H., Ikeda, N., Kobayashi, K., Terashima, Y., Shimada, Y., Suzuki, T. Hayashi, M. (2005). Evaluation of liver and peripheral blood micronucleus assays with 9 chemicals using young rats. Mutation Research, 583(2), 133-145. https://doi.org/10.1016/j.mrgentox.2005.03.012

Swaileh, K.M., Hussein, R., \& Ezzughayyar, A. (2008). Evaluating wastewater-induced plant genotoxicity using randomly amplified polymorphic DNA. Environmental Toxicology, 23(1), 117-122. https://doi.org/10.1002/tox.20316

Takakura, N., Nesslany, F., Fessard, V., \& Le Hegarat, L. (2014). Absence of in vitro genotoxicity potential of the mycotoxin deoxynivalenol in bacteria and in human TK6 and HepaRG cell lines. Food and Chemical Toxicology, 66, 113-121. https://doi.org/10.1016/i.fct.2014.01.029

Tatay, E., Espín, S., García-Fernández, A.J., \& Ruiz, M.J. (2017). Oxidative damage and disturbance of antioxidant capacity by zearalenone and its metabolites in human cells. Toxicology in Vitro: An International Journal 
Published in Association with BIBRA, 45(3), 334-339. https://doi.org/10.1016/j.tiv.2017.04.026

Tatay, E., Font, G., \& Ruiz, M.J. (2016). Cytotoxic effects of zearalenone and its metabolites and antioxidant cell defense in CHO-K1 cells. Food and $\begin{array}{llll}\text { Chemical Toxicology, } & 96, & \text { 43-49. }\end{array}$ https://doi.org/10.1016/i.fct.2016.07.027

Test No. 473: In vitro Mammalian Chromosome Aberration Test. Retrieved December 6, 2019, from https://www.oecdilibrary.org/environment/test-no-473-in-vitro-mammalianchromosome-aberration-test_9789264071261-en

Test No. 474: Mammalian Erythrocyte Micronucleus Test. Retrieved December 6, 2019, from https://www.oecdilibrary.org/environment/test-no-474-mammalian-erythrocytemicronucleus-test_9789264264762-en

Test No. 475: Mammalian Bone Marrow Chromosomal Aberration Test. Retrieved December 6, 2019, from https://www.oecdilibrary.org/environment/test-no-475-mammalian-bone-marrowchromosomal-aberration-test_9789264224407-en

Test No. 479: Genetic Toxicology: In vitro Sister Chromatid Exchange Assay in Mammalian Cells. Retrieved December 6, 2019, from https:// www.oecd-ilibrary.org/environment/test-no-479-genetictoxicology-in-vitro-sister-chromatid-exchange-assay-in-mammaliancells_9789264071384-en

Theumer, M.G., Cánepa, M.C., López, A.G., Mary, V.S., Dambolena, J.S., \& Rubinstein, H.R. (2010). Subchronic mycotoxicoses in Wistar rats: Assessment of the in vivo and in vitro genotoxicity induced by fumonisins and aflatoxin $\mathrm{B}(1)$, and oxidative stress biomarkers status. Toxicology, 268(1-2), https://doi.org/10.1016/i.tox.2009.12.007

Thust, R., \& Kneist, S. (1979). Activity of citrinin metabolized by rat and human microsome fractions in clastogenicity and SCE assays on Chinese hamster V79-E cells. Mutation Research, 67(4), 321-330. https://doi.org/10.1016/0165-1218(79)90028-4

Thust, R., Kneist, S., \& Hühne, V. (1983). Genotoxicity of Fusarium mycotoxins (nivalenol, fusarenon- $\mathrm{X}, \mathrm{T}-2$ toxin, and zearalenone) in Chinese hamster V79-E cells in vitro. Archiv Fur Geschwulstforschung, 53(1), 9-15.

Tiessen, C., Ellmer, D., Mikula, H., Pahlke, G., Warth, B., Gehrke, H., ... Marko, D. (2017). Impact of phase I metabolism on uptake, oxidative stress and genotoxicity of the emerging mycotoxin alternariol and its monomethyl ether in esophageal cells. Archives of Toxicology, 91(3), 1213-1226. https://doi.org/10.1007/s00204-016-1801-0

Tiessen, C., Fehr, M., Schwarz, C., Baechler, S., Domnanich, K., Böttler, U., .. Marko, D. (2013). Modulation of the cellular redox status by the Alternaria toxins alternariol and alternariol monomethyl ether. $\begin{array}{lll}\text { Toxicology Letters, 23-30. } & \text { 216(1), }\end{array}$ https://doi.org/10.1016/i.toxlet.2012.11.005

Tikkanen, L., Matsushima, T., \& Natori, S. (1983). Mutagenicity of anthraquinones in the Salmonella preincubation test. Mutation Research, 116(3-4), 297-304. https:// doi.org/10.1016/0165-1218(83)90067-8

Topaktas, M., \& Rencuzogullari, E. (2010). Sitogenetik (Cytogenetic). Ankara, Turkey. Nobel Press

Tsuda, S., Kosaka, Y., Murakami, M., Matsuo, H., Matsusaka, N., Taniguchi, K., \& Sasaki, Y.F. (1998). Detection of nivalenol genotoxicity in cultured cells and multiple mouse organs by the alkaline single-cell gel electrophoresis assay. Mutation Research, 415(3), 191-200. https://doi.org/10.1016/s1383-5718(98)00068-0

Tucker, J.D., Auletta, A., Cimino, M.C., Dearfield, K.L., Jacobson-Kram, D., Tice, R.R., \& Carrano, A.V. (1993). Sister-chromatid exchange: Second report of the Gene-Tox Program. Mutation Research, 297(2), 101-180. https://doi.org/10.1016/0165-1110(93)90001-4

Tyson, C.K., \& Mirsalis, J.C. (1985). Measurement of unscheduled DNA synthesis in rat kidney cells following in vivo treatment with genotoxic

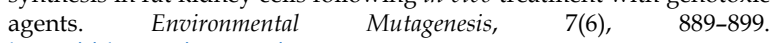
https://doi.org/10.1002/em.2860070610

Uhl, M., Helma, C., \& Knasmüller, S. (2000). Evaluation of the single cell gel electrophoresis assay with human hepatoma (Hep G2) cells. Mutation Research, 468(2), 213-225. https://doi.org/10.1016/s13835718(00)00051-6

Umeda, M., Tsutsui, T., \& Saito, M. (1977). Mutagenicity and inducibility of DNA single-strand breaks and chromosome aberrations by various mycotoxins. Gann Japanese Journal of Cancer Research, 68(5), 619-625.

Unlu, S., \& Saglar, E. (2015). Evaluation of Cytogenetic and Genotoxic Effects of Oxalic Acid by the Alkaline Comet Assay and QRT PCR in Human Buccal Epithelial Cells. Analytical and Quantitative Cytopathology and Histopathology, 37(6), 347-352.

Van den Heever, J.P., Thompson, T.S., Curtis, J.M., \& Pernal, S.F. (2015). Stability of dicyclohexylamine and fumagillin in honey. Food Chemistry, 179, 152-158. https://doi.org/10.1016/j.foodchem.2015.01.111
Van Went, G.F. (1978). Mutagenicity testing of 3 hallucinogens: LSD, psilocybin and delta 9-THC, using the micronucleus test. Experientia, 34(3), 324-325. https:// doi.org/10.1007/bf01923013

Venier, P., Montini, R., Zordan, M., Clonfero, E., Paleologo, M. \& Levis, A.G. (1989). Induction of SOS response in Escherichia coli strain PQ37 by 16 chemical compounds and human urine extracts. Mutagenesis, 4(1), 51-57. https://doi.org/10.1093/mutage/4.1.51

Wang, J.C., \& Qian, B.L. (1997). Detection of DNA damage in peripheral lymphocytes by 7 compounds using comet assay. Zhongguo Yao Li Xue Bao = Acta Pharmacologica Sinica, 18(5), 451-454.

Wangenheim, J., \& Bolcsfoldi, G. (1988). Mouse lymphoma L5178Y thymidine kinase locus assay of 50 compounds. Mutagenesis, 3(3), 193205. https://doi.org/10.1093/mutage/3.3.193

Wehner, F.C., Marasas, W.F., \& Thiel, P.G. (1978a). Lack of mutagenicity to Salmonella typhimurium of some Fusarium mycotoxins. Applied and Environmental Microbiology, 35(4), 659-662.

Wehner, F.C., Thiel, P.G., \& Vleggaar, R. (1979). Mutagenicity of 5,6dimethoxysterigmatocystin, a metabolite from Aspergillus multicolor, in the Salmonella/microsome system. Applied and Environmental Microbiology, 38(5), 1015-1017.

Wehner, F.C., Thiel, P.G., van Rensburg, S.J., \& Demasius, I.P.C. (1978b). Mutagenicity to Salmonella typhimurium of some Aspergillus and Penicillium mycotoxins. Mutation Research, 58(2), 193-203. https://doi.org/10.1016/0165-1218(78)90009-5

Wei, C.I., Huang, T.S., Fernando, S.Y., \& Chung, K.T. (1991). Mutagenicity studies of kojic acid. Toxicology Letters, 59(1-3), 213-220. https://doi.org/10.1016/0378-4274(91)90074-g

Williams, J.G., Deschl, U., \& Williams, G.M. (2011). DNA damage in fetal liver cells of turkey and chicken eggs dosed with aflatoxin B1. Archives of Toxicology, 85(9), 1167-1172. https://doi.org/10.1007/s00204-0110653-x

Williams, J.G., Kubelik, A.R., Livak, K.J., Rafalski, J.A., \& Tingey, S.V. (1990). DNA polymorphisms amplified by arbitrary primers are useful as genetic markers. Nucleic Acids Research, 18(22), 6531-6535. https://doi.org/10.1093/nar/18.22.6531

Wilson, W.R., Harris, N.M., \& Ferguson, L.R. (1984). Comparison of the mutagenic and clastogenic activity of amsacrine and other DNAintercalating drugs in cultured V79 Chinese hamster cells. Cancer Research, 44(10), 4420-4431.

Wong, J.J., Singh, R., \& Hsieh, D.P. (1977). Mutagenicity of fungal metabolites related to aflatoxin biosynthesis. Mutation Research, 44(3), 447-450. https:// doi.org/10.1016/0027-5107(77)90102-6

Würgler, F.E., Friederich, U., \& Schlatter, J. (1991). Lack of mutagenicity of ochratoxin A and B, citrinin, patulin and cnestine in Salmonella typhimurium TA102. Mutation Research, 261(3), 209-216. https:// doi.org/10.1016/0165-1218(91)90069-X

Xu, J., Whong, W.Z., \& Ong, T. (1984). Validation of the Salmonella (SV50)/arabinose-resistant forward mutation assay system with 26 compounds. Mutation Research, 130(2), 79-86. https://doi.org/10.1016/0165-1161(84)90107-9

Yamamoto, K.N., Hirota, K., Kono, K., Takeda, S., Sakamuru, S., Xia, M., ... Tice, R.R. (2011). Characterization of environmental chemicals with potential for DNA damage using isogenic DNA repair-deficient chicken DT40 cell lines. Environmental and Molecular Mutagenesis, 52(7), 547-561. https://doi.org/10.1002/em.20656

Yang, T.H., Wu, T.H., Chang, Y.L., Liao, H.T., Hsu, C.C., Tsai, C.Y., \& Chou, Y.C. (2018). Cyclosporine for the treatment of lupus nephritis in patients with systemic lupus erythematosus. Clinical Nephrology, 89(4), 277-285. https://doi.org/10.5414/CN109325

Yang, W., Yu, M., Fu, J., Bao, W., Wang, D., Hao, L., ... Liu, L. (2014). Deoxynivalenol induced oxidative stress and genotoxicity in human peripheral blood lymphocytes. Food and Chemical Toxicology, 64, 383396. https://doi.org/10.1016/i.fct.2013.12.012

Yen, G.C., Chang, Y.C., Sheu, F., \& Chiang, H.C. (2001). Isolation and characterization of antioxidant compounds from Aspergillus candidus broth filtrate. Journal of A gricultural and Food Chemistry, 49(3), 1426-1431. https://doi.org/10.1021/if001109t

Yourtee, D.M., \& Kirk-Yourtee, C.L. (1986). The mutagenicity of aflatoxin Q1 to Salmonella typhimurium TA 100 with or without rat or human liver microsomal preparations. Research Communications in Chemical Pathology and Pharmacology, 54(1), 101-113.

Yuzawa, K., Kondo, I., Fukao, K., Iwasaki, Y., \& Hamaguchi, H. (1986). Mutagenicity of cyclosporine. Induction of sister chromatid exchange in human cells. Transplantation, 42(1), 61-63.

Zain, M.E. (2011). Impact of mycotoxins on humans and animals. Journal of Saudi Chemical Society, 15(2), 129-144. https://doi.org/10.1016/i.jscs.2010.06.006 
Zeljezić, D., Domijan, A.M., \& Peraica, M. (2006). DNA damage by ochratoxin A in rat kidney assessed by the alkaline comet assay. Brazilian Journal of Medical and Biological Research, 39(12), 1563-1568. https://doi.org/10.1590/s0100-879x2006001200006

Zhang, D., Cui, Y., Shen, H., Xing, L., Cui, J., Wang, J., \& Zhang, X. (2013). Sterigmatocystin-induced DNA damage triggers G2 arrest via an ATM/p53-related pathway in human gastric epithelium GES-1 cells in

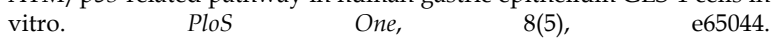
https://doi.org/10.1371/journal.pone.0065044

Zhang, J., Zheng, N., Liu, J., Li, F.D., Li, S.L., \& Wang, J.Q. (2015). Aflatoxin $\mathrm{B} 1$ and aflatoxin M1 induced cytotoxicity and DNA damage in differentiated and undifferentiated Caco-2 cells. Food and Chemical Toxicology, 83, 54-60. https://doi.org/10.1016/i.fct.2015.05.020

Zhang, X., Jiang, L., Geng, C., Cao, J., \& Zhong, L. (2009). The role of oxidative stress in deoxynivalenol-induced DNA damage in HepG2 cells. Toxicon, 54(4), 513-518. https://doi.org/10.1016/j.toxicon.2009.05.021

Zhang, Y.F., Yang, J.Y., Li, Y.K., \& Zhou, W. (2017). Toxicity and oxidative stress induced by T-2 toxin in cultured mouse Leydig cells. Toxicology Mechanisms and Methods, 27(2), 100-106. https://doi.org/10.1080/15376516.2016.1258747

Zhang, Z., Fu, J., Yao, B., Zhang, X., Zhao, P., \& Zhou, Z. (2011). In vitro genotoxicity of danthron and its potential mechanism. Mutation Research, 722(1), 39-43. https://doi.org/10.1016/j.mrgentox.2011.02.006

Zhiyi, R., \& Haowen, Y. (2004). A method for genotoxicity detection using random amplified polymorphism DNA with Danio rerio. Ecotoxicology
Safety,

and

Environmental

58(1),

96-103. https://doi.org/10.1016/j.ecoenv.2003.09.016

Zhou, S., Jiang, L., Geng, C., Cao, J., \& Zhong, L. (2010). Patulin-induced oxidative DNA damage and p53 modulation in HepG2 cells. Toxicon, 55(2), 390-395. https:// doi.org/10.1016/j.toxicon.2009.08.019

Zurlo, J., Roebuck, B.D., Rutkowski, J.V., Curphey, T.J., \& Longnecker, D.S. (1984). Effect of pyridoxal deficiency on pancreatic DNA damage and nodule induction by azaserine. Carcinogenesis, 5(5), 555-558. https://doi.org/10.1093/carcin/5.5.555

Zwanenburg, T.S., \& Cordier, A. (1994). No cyclosporin-induced chromosomal aberrations in human peripheral blood lymphocytes in vitro. Mutation Research, 320(3), 217-221. https://doi.org/10.1016/01651218(94)90048-5 